IZA DP No. 8171

Viral Altruism?

Generosity and Social Contagion in Online Networks

Nicola Lacetera

Mario Macis

Angelo Mele

May 2014 


\title{
Viral Altruism? \\ Generosity and Social Contagion in Online Networks
}

\author{
Nicola Lacetera \\ University of Toronto \\ Mario Macis \\ Johns Hopkins University - Carey Business School \\ and IZA \\ Angelo Mele \\ Johns Hopkins University - Carey Business School
}

\author{
Discussion Paper No. 8171 \\ May 2014
}

IZA
P.O. Box 7240
53072 Bonn
Germany

Phone: +49-228-3894-0

Fax: +49-228-3894-180

E-mail: iza@iza.org

\begin{abstract}
Any opinions expressed here are those of the author(s) and not those of IZA. Research published in this series may include views on policy, but the institute itself takes no institutional policy positions. The IZA research network is committed to the IZA Guiding Principles of Research Integrity.

The Institute for the Study of Labor (IZA) in Bonn is a local and virtual international research center and a place of communication between science, politics and business. IZA is an independent nonprofit organization supported by Deutsche Post Foundation. The center is associated with the University of Bonn and offers a stimulating research environment through its international network, workshops and conferences, data service, project support, research visits and doctoral program. IZA engages in (i) original and internationally competitive research in all fields of labor economics, (ii) development of policy concepts, and (iii) dissemination of research results and concepts to the interested public.
\end{abstract}

IZA Discussion Papers often represent preliminary work and are circulated to encourage discussion. Citation of such a paper should account for its provisional character. A revised version may be available directly from the author. 


\section{ABSTRACT \\ Viral Altruism? \\ Generosity and Social Contagion in Online Networks}

How do the social media affect the success of charitable promotional campaigns? We use individual-level longitudinal data and experimental data from a social-media application that facilitates donations while broadcasting donors' activities to their contacts. We find that broadcasting is positively associated with donations, although some individuals appear to opportunistically broadcast a pledge, and then delete it. Furthermore, broadcasting a pledge is associated with more pledges by a user's contacts. However, results from a field experiment where broadcasting of the initial pledges was randomized suggest that the observational findings were likely due to homophily rather than genuine social contagion effects. The experiment also shows that, although our campaigns generated considerable attention in the forms of clicks and "likes," only a small number of donations (30 out of 6.4 million users reached) were made. Finally, an online survey experiment showed that both the presence of an intermediary and a fee contributed to the low donation rate. Our findings suggest that online platforms for charitable giving may stimulate costless forms of involvement, but have a smaller impact on actual donations, and that network effects might be limited when it comes to contributing real money to charities.

JEL Classification: D64, C93

Keywords: altruism, fundraising, social media, network effects, field experiments

Corresponding author:

Mario Macis

Johns Hopkins University

Carey Business School

100 International Dr.

Baltimore, MD 21202

USA

E-mail:mmacis@jhu.edu

\footnotetext{
* We thank Ehren Foss and Vanessa Swesnik at HelpAttack!, and Casey Neese at Heifer International for their help and collaboration. We also thank Michael Price and participants at the ASSA Meetings in Philadelphia for useful comments. Financial support from the NET Institute (www.NETinst.org) and the Johns Hopkins Carey Business School Small Grants Program is acknowledged. The study was conducted with approval from the HIRB at Johns Hopkins University and the Office for Research Ethics at the University of Toronto.
} 


\section{Introduction}

Firms are increasingly relying on the Internet for their marketing strategies. In the U.S. only, marketers are estimated to spend over $\$ 30$ billion annually in online advertising (an amount similar to the expenses for advertising on broadcast TV and about 50\% larger than newspaper advertising), with an ever positive trend anticipated in the future years (Coady Diemar 2012). Advertising-based business models characterize many Internet-based companies, including the largest ones like Google or Facebook. Moreover, e-commerce sales currently surpass \$1 trillion, and also many traditional "brick-and-mortar" stores are increasing their online presence (eMarketer 2013, Jopson 2013). The Internet, in principle, allows companies to reach a large number of customers at virtually zero marginal costs. In addition social media may compound the reach of promotional campaigns through social contagion and network effects. ${ }^{1}$

The optimism about the potential of the Internet, and social media in particular, to expand the consumer base has spread from for-profit companies to charitable and other non-profit organizations. In this paper we study, with both observational and field-experimental data, the performance of online fundraising campaigns, and the existence of network effects for donations to charities in this context.

In principle, the Web offers charities an opportunity to efficiently reach a large number of individuals in a short time, and network effects can further boost donations. Peer effects and social pressure have been identified as affecting pro-social behavior, and a few recent studies found similar correlations for online charitable giving. ${ }^{2}$ These advantages could especially benefit smaller, less known organizations that cannot afford the high fixed costs of more standard, offline promotional campaigns. Charitable organizations, therefore, increasingly use online channels to encourage new and existing donors to give (Blackbaud 2013). Examples of pro-social causes that went "viral" include the Kony2012 and the "Bullied Bus Monitor" campaigns, as well as the Facebook feature that allows broadcasting one’s status as an organ donor (Cameron et al. 2013).

In spite of this potential, online fundraising currently only accounts for $7 \%$ of the total (Blackbaud 2013). This amount is bound to increase given the current trends; however, the small incidence of online fundraising might also be due to some limitations of the online environment, and, in particular, to some features of the social media that make it difficult, or costly, for charities to raise funds. Expressions such as "slacktivism" or "illusion of activism," for example, indicate that, although many people express support for a cause by, for example "liking" or "favoring" a post on Facebook or Twitter, most of them do

\footnotetext{
${ }^{1}$ Studies on how social networks and processes such as word-of-mouth communication allow firms to reach a disproportionately large number of potential customers at low costs include Aral and Walker (2011), Bapna and Umyarov (2014), Manchanda et al. (2008), Moretti (2011), and Nam et al. (2010).

${ }^{2}$ See for example Ashraf et al. (2012); DellaVigna et al. (2012); Lacetera and Macis (2010); Meer (2011); Shang and Croson (2009); and Smith et al. (2013). Castillo et al. (2014) perform an experiment on peer-to-peer effects in online fundraising.
} 
not follow up with an actual donation or active engagement (Kristofferson et al. forthcoming; Lewis et al. 2014). If social-image concerns motivate pro-social behavior, then the possibility provided by social media to costlessly express support for a cause and display it in public might satisfy the individuals' desire to "look good" without them having to actually engage in costly activities such as donating money or volunteering (Kristofferson et al., forthcoming). Similarly, individuals might obtain some personal utility or "warm glow" from costless activities on social media, thus substituting more costly alternatives such as actual contributions. Collective action problems are likely to characterize the online environment. Given the large number of individuals potentially involved, incentives to participate actively are low (Lewis et al. 2014). Also, as implied by Tucker (2012), an explicit reference to the pro-social behavior (or lack thereof) of one's contacts on social media might generate a sense of intrusiveness and lead to less pro-social behavior by peers. Finally, ad click-through rates on social media sites are notoriously very low (Kim 2012), implying that a very large number of users need to be reached for any meaningful effects to be obtained. One implication is that the impact of online campaigns, if any, might be short-lived, thus further increasing fundraising costs. After the immediate increase in organ donor registrations following the introduction of the donor status on Facebook, for example, registrations rates rapidly reverted to baseline levels (Cameron et al. 2013); and the Kony2012 "Cover the Night" campaign was no as successful as expected, despite the viral success of the online video. ${ }^{3}$ High competition for consumer attention has also been indicated as a major obstacle for online advertising activities of for-profit companies, and for advertising-based business models (Teixeira 2014).

Thus, because of some peculiarities of online interactions and of charitable activities, it is challenging to apply theories and findings from offline charitable activities, and to extrapolate insights from studies of online dynamics such as contagion and network effects as they apply to other contexts, such as product adoption and sales. The relatively scant literature on online charitable giving, and the importance of nonprofit organizations and charities in supplying essential goods and services (e.g., disaster relief, food to people in need, blood to hospitals, etc.) thus call for more empirical analyses. Fortunately for researchers, the use of online channels by charities offers new possibilities to exploit these platforms as laboratories to better understand online donation behavior and the effects of certain fundraising strategies.

For our study, we collaborated with HelpAttack! (HA henceforth), the developer of an application that allows users to donate to charities through Facebook status updates and Twitter tweets. The HA application allows users to broadcast their initial pledge and subsequent donations to some or all of their

\footnotetext{
3 "While the London event has almost 3,000 'likes' and 1,300 people say they will attend in Reading, Birmingham has mustered the support of just 35 people, with a mere 14 in Norwich. Organisation seems even more patchy. A day before the planned protest the Reading page said locations and events 'are yet to be finalized'." (http://www.theguardian.com/world/blog/2012/apr/20/kony-2012-cover-the-night).
} 
contacts. We begin by analyzing the full historical HA dataset consisting of 3,460 pledges made by 820 unique Twitter or Facebook users in the period 8/2010-12/2012. First, we assess the role of broadcasting one's pledge on the actually fulfillment of the pledge. On the one hand, broadcasting one's involvement can increase the probability of going through with the donation. This could happen, for instance, if broadcasting acts as a form of "soft commitment" (Bryan et al. 2010). In fact, even though deleting a pledge made through HA does not carry any actual economic or reputational cost, doing so might cause a psychological cost to the user (e.g., disappointment, or loss of self-esteem from breaking a promise). On the other hand, making one's involvement public might also substitute for donating higher amounts. Because HA broadcasts the initial pledge, a users' social image is immediately affected at the time the pledge is made, irrespective of whether any payment is ultimately made to the charity. About $16 \%$ of pledges made through HA were subsequently deleted, and the proportion of deleted pledges was higher for users who broadcasted their initial pledge. Regression analyses that control for individual heterogeneity show that broadcasting is positively correlated with the share of a pledge that is actually fulfilled, and negatively associated with the probability of deleting a pledge. The difference between the raw correlations and the regression results indicates that individuals who are more likely to delete a pledge also choose to broadcast their pledges, on average. This is consistent with a subset of users displaying some opportunism in their use of the HA app.

Second, we explore the existence of network effects. About 5\% of initial pledges resulted in additional pledges by contacts (friends or followers) of the original donors, and most of these additional pledges were from contacts of users who broadcasted their activity. However, the occurrence of additional pledges by contacts of the original donors is hard to interpret as evidence of the existence of a network effect when relying on observational data (Shalizi and Thomas 2011). These pledges may be driven by homophily, i.e. that fact that individuals tend to interact with similar people. ${ }^{4}$ Also, users in the same circles are exposed to similar events and influences that make them behave similarly -- for example, the temporal profile of pledges through HA shows spikes, some of which correspond to natural disasters (e.g., the March 2011 Tsunami in Japan), and others, presumably, to local events or fundraising efforts by specific charities. Further, donors might choose to broadcast their activity only to contacts who are more likely to also behave pro-socially.

To overcome these issues, we conducted a field experiment during June-August 2012. We used a combination of Facebook ads and sponsored stories that invited users to make donations through HA to Heifer International, a non-profit organization aimed at fighting poverty in developing countries. The experimental manipulation consisted of randomly turning off (control) and on (treatment) the broadcasting feature of the application for each individual adopter. Thus, for users in the control group,

\footnotetext{
${ }^{4}$ Evidence of homophily in friendship patterns on Facebook has been shown by Lewis et al. (2011).
} 
any donation activity was private to the individual, whereas for users in the treatment group, any donation activity was automatically notified to their contacts. This strategy enabled us to causally identify and quantify the social multiplier or network effect, in the number of pledges and donations, and amounts pledged and donated, and to determine whether the size of the multiplier was associated with the initial user's characteristics (e.g., number of contacts, number of followers, etc.). Our campaigns reached a total of about 6.4 million Facebook users.

We first find, consistent with the historical data, that actual donations were very limited. Almost 6,000 users clicked on the ads (roughly in line with Facebook click-through rates for non-profit ads [Kim 2012]); support was expressed through "likes" (2,008), "shares" (303), and comments (213), whereas only 30 users (16 in the treatment and 14 in the control group) installed the application and pledged some money. Second, we do not find evidence, in this controlled setting, of network effects. Of the treatment group's 2,275 contacts, none made further pledges.

Our marketing campaigns were on a large scale, but it can be argued that an even bigger intervention would have generated more initial pledges, thus increasing the likelihood of network effects. However, conducting these campaigns on Facebook is costly. In our study, for each dollar raised for the charity we spent $\$ 13.5$ to pay for the Facebook ads. There is little value in estimating an effect that is economically very small, especially when the cost of statistical precision is so high. ${ }^{5}$

Thus, although there is evidence of the success of online promotional campaigns and of peer influence in other online contexts, as in the case of applications to write and share movie recommendations (Aral and Walker 2011) or to install premium versions of music services (Bapna and Umyarov 2014), in our study, where users were invited to make monetary donations to a charity, both the direct and indirect or network responses were very limited, if existent at all.

We complemented our analysis based on HA with a computerized survey experiment to further investigate the potential reasons for the very small donation rates. About 1,600 US respondents on Amazon Mechanical Turk were asked about their willingness to donate \$5 out of a hypothetical endowment of $\$ 10$ to a charity. The survey used the "Item Count Technique" to allay concerns for social desirability bias (Coffman et al. 2013; Miller 1984), and respondents were randomly assigned different versions of the questions, where the manipulations were meant to capture the key features of the HA app and of our experiment: the target charity (Red Cross, Heifer, charity of choice), the presence of a fee, and the presence of a third party (an intermediary) to collect the fee. The presence of a fee, the mention of an intermediary, and the focus on a specific charity with lower salience (i.e., Heifer), all concurred to depress the stated donation rates significantly.

\footnotetext{
${ }^{5}$ Blake et al. (2014) provide evidence of the very low effectiveness of online ads.
} 
Overall, our study highlights a number of peculiar challenges for charitable organizations that aim to leverage the potential power of online promotional campaigns to generate more contributions both directly and through social multiplier effects. In particular, charitable organizations might need to be explicit in asking for actual monetary support online that cannot be substituted with "costless" activities (such as a "like" or "share"), and opt for business models that limit the reliance on administrative fees as well as the involvement of third parties. Moreover, although in principle online campaigns and reliance on contagion effects might substitute for large, traditional offline campaigns and thus favor smaller and less recognizable charities, in fact offline recognition appears as a necessary complement to the success of online initiatives. The results also suggest that much of what might seem network effects in charitable giving from the observational data are due to confounding factors. More generally, our findings may offer further insights to the literature on the relationship between online and offline advertising and targeting (Athey and Gans 2010; Bergemann and Bonatti 2011; Goldfarb and Tucker 2011).

The paper proceeds as follows. In Section 2, we provide some background on Helpattack!. Section 3 describes the historical data and illustrates the patterns that emerge from their analysis. Our field experiment is reported in Section 4, and the survey is described in Section 5. Section 6 concludes.

\section{Helpattack!}

HelpAttack! (HA henceforth) is a company that developed an application through which Facebook and Twitter users can donate to a charity of their choice via Facebook updates, tweets, or blog posts. The user pledges an amount of money (e.g. \$20), and decides the rate per update (e.g. 20c per Facebook update). Each time the user updates her Facebook status, the application records a donation to the charity. The HA application allows users to broadcast their initial pledge and subsequent donations to their Facebook friends or Twitter followers. The default is that the "broadcasting" feature of the application is turned on, unless the user decides to turn it off (by checking a box). Pledges can be either fulfilled or deleted by the user without penalty. Once a pledge has been completed, users are requested to enter their credit card information. ${ }^{6}$ The application automatically sends several broadcasting messages of the donation activity to the users' friends: one at the moment of the initial pledge, one after a few days, one after the user reached half of the total amount pledged, and one at the end of the period. Once users install the HA application and make a pledge to a charity, they also give permission to the app to monitor their donation activity and download information from their public profile. The company keeps $8.25 \%$ of each donation

\footnotetext{
${ }^{6}$ Payments are handled by an external company, FirstGiving. HelpAttack! does not store any financial or credit card information from the users.
} 
(also to cover credit cards fees and administrative costs). HA began their operations in August 2010, and closed in December 2012 when it was acquired by we-care.com. ${ }^{7}$

We have access to HA's (anonymized) database of pledges and donors, and we used the application to implement the randomization for our field experiment. Figure 1A shows an example of HA's pledge page, Figure 1B the pledge page where the user can customize the viral features of the HA broadcast, and Figure 1C shows some examples of broadcasted messages as they appear on the user's Facebook timeline.

\section{Analysis of the observational data}

\subsection{Descriptive statistics}

The historical data contains the entire database of pledges for 820 unique users in the period August 2010 - December 2012. There are 3,460 pledges in total, almost $\$ 200,000$ pledged, and donations of about $\$ 81,000$. The most popular charities (i.e., those with at least 50 pledges) are shown in Table 1 . More than half of the pledges were concentrated in ten charities, with the American Red Cross being the most popular organization with 714 pledges (20.63\% of the total), followed by Best Friend Animal Society with 357 pledges. $^{8}$

As shown in Table 2, about 43\% of pledges were made through Facebook, and 57\% via Twitter. The average amount pledged on Facebook is slightly larger than that pledged on Twitter (\$66 vs. \$57), although the median amounts are the same (\$40). As for actual donations, both the average and median amounts are larger for Facebook than for Twitter (\$35 vs. \$27 for the mean, and \$31 vs. \$20 for the median). ${ }^{9}$ The rate-per-update/tweet (i.e., the amount of money that goes toward the goal of the pledge every time the user updates her Facebook status or makes a tweet on Twitter) are larger on Facebook than on Twitter (about $\$ 1$ vs. $\$ 0.50$ on average, and $\$ 0.50$ vs. $\$ 0.10$ for the median). Table 3 shows mean and median amounts pledged and donated, as well as the rates-per-update separately for each of the most popular charities on HA. There is substantial heterogeneity across charities along all dimensions.

When we examine the timeline of donations, overall and by charity, we observe spikes in new pledges at certain dates, some of which coincide with catastrophic events and, presumably, fundraising campaigns. For example, Figure 4 shows the new pledges for the American Red Cross, by starting date. In 2011 there are several spikes, which coincide with the Japanese Earthquake/Tsunami in March 2011, and the Tornado outbreak in the US culminated with the EF5 tornado in Joplin (May 2011).

\footnotetext{
${ }^{7}$ See http://www.we-care.com/blog/2013/prhelpattack. HA's original webpage was https://www.helpattack.com/.

8 The website of HA contains 7,373 charities, 343 of which received at least one pledge.

${ }^{9}$ Some charities almost entirely rely on Facebook for their HA donations (e.g., Homes for our Troops Inc., Autism Society of America), whereas others have a higher number of pledges from Twitter (e.g., Mobile, Loaves and Fishes, NTEN). These details are not shown in the tables to save space but can be provided upon request.
} 


\subsection{Analysis of donation activities on HA}

It is difficult to establish if a total of 3,460 pledges and $\$ 81,000$ collected are large or small amounts. We do analyze, however, how much of the activity and traffic on HA's webpage was generated by actual engagement through pledges and donations. During the period August 2010 - December 2012, the HA website had stable traffic of about 2,500 unique visitors per month. Thus, the 820 users who made at least one pledge correspond to approximately $1 \%$ of the total number of users who accessed the website.

Table 1 shows that $64 \%$ of pledges were fulfilled (i.e., they were honored with a payment to the selected charity of at least the amount pledged), and $12.5 \%$ were partially fulfilled (i.e., a payment was made for an amount smaller than the amount pledged). ${ }^{10}$ In about $16 \%$ of cases, pledges were deleted before being paid, and therefore did not result in an actual donation. ${ }^{11}$ The fact that a substantial share of pledges are deleted clearly reduces the proceeds generated though the HA application and, as such, warrants some attention. There is also substantial heterogeneity across charities in the share of pledges fulfilled (totally or partially) and deleted. For example, Habitat for Humanity International received 39 pledges, but only 1 of those was processed and paid to the organization, whereas Mobile Loaves and Fishes received a total of 114 pledges, and 97 of them were processed and paid.

Whether a pledge is fulfilled or not presents additional elements of interest in this context. First, this can be informative about different motivations for pro-social behavior. In particular, HA users can, in principle, behave opportunistically by pledging to donate some money, broadcasting their pledge to their contacts, and subsequently deleting the donation, without any repercussions on their reputation. It is also possible, however, that broadcasting a pledge could act as a form of "soft commitment" (Bryan et al. 2010) that might make it more likely for the user to go through with the donation. Second, it is important to consider the deleted pledges when estimating network effects, because the HA application posts a message on the Facebook (or Twitter) timeline when a pledge is started. Even when the pledge is deleted later on, this initial message may be sufficient to trigger a network effect, attracting new donors.

The regression analyses reported in Table 4 examine the relationship between whether a users' activity was broadcasted and two outcome variables, namely the share of a pledge that is fulfilled, and the likelihood of a pledge being deleted. We performed linear regressions that control for the characteristics of the pledge (its amount and time duration), as well as past pledging and donation behavior of the user (the total number of pledges made in the past, and the total amount of money actually donated to charities

\footnotetext{
10 1.4\% of pledges were inactive (i.e., the user did not have any activity for several weeks), and $6.2 \%$ were still active (i.e., they did not reach the end of the pledge period). We removed active and inactive pledges in all of our analyses below.

${ }^{11}$ No payment is due until the pledge period is over. The user can delete the pledge at any time before the end of the period. However, she may partially fulfill the pledge or pay in full before the end of the pledge period.
} 
through HA up to the date of the current pledge). ${ }^{12}$ We then added charity and individual fixed effects in order to control for unobserved heterogeneity. ${ }^{13}$ When individual fixed effects are included, we estimate a positive association between broadcasting and the share of pledges actually fulfilled. As shown in Panel A of Table 4 (Column 4), broadcasting a pledge leads to a 9 percentage-point increase in the share of the pledge that is fulfilled, or $14.5 \%$ of the baseline fulfillment rate of $62 \%$.

Controlling for charity and individual unobserved heterogeneity is even more crucial for the interpretation of the results when we analyze the correlates of the likelihood of deleting a pledge (Table 4, Panel B). Regressions that do not include charity and individual fixed effects (column 1) estimate a positive and statistically significant association between broadcasting a pledge and deleting it. The association between broadcasting and deleting a pledge could be due to broadcasting the pledge causing users to subsequently delete it (Kristofferson et al., forthcoming), but could also be driven by omitted variables and, more generally, unobservable individual heterogeneity. For instance, if users who are intrinsically opportunistic choose to use the HA app to satisfy their desire to "look good" by making a pledge, broadcast it, and subsequently delete it (with no penalty or negative publicity), this might create a positive correlation in the data between broadcasting and deleting. Also, in Table 1 we noted that different charities varied considerably in the share of pledges that were subsequently deleted, suggesting potential heterogeneity among charities potentially related to the association between broadcasting and deleting. The addition of charity and individual fixed effects leads to negative and significant estimates on the coefficient of interest, larger when individual fixed effects are included. This indicates that individuallevel heterogeneity also exists among users who give to the same charity. Our fully specified model (Column 4) implies that broadcasting one's pledge is associated with a 14.3 percentage-point reduction in the probability of subsequently deleting it. Essentially, once charity and user heterogeneity are accounted for, the probability of deleting a pledge is almost entirely removed. One interpretation of this effect is that broadcasting acts as form of "soft commitment," whereby failure to comply with the promise made carries a psychological cost (e.g. loss of self-esteem) which induces users to follow through with the donation they publicly pledged to make (Bryan et al. 2010).

\footnotetext{
${ }^{12}$ For the analyses using whether a pledge was deleted as the outcome variable, we used linear models instead of nonlinear, binary-outcome specifications because we could conveniently include charity and user fixed effects without running into incidental-parameter problems (Angrist and Pischke 2009).

${ }^{13}$ Almost $15 \%$ of users donate to more than one charity. The activity of these users corresponds to about $38 \%$ of all the pledges. The average charity has 3.31 users and $37 \%$ of the charities have pledges from at least two users.
} 


\subsection{Exploring Network Effects}

The broadcasting feature of HA can potentially trigger additional donations for the charitable organizations. If a Facebook or Twitter contact of a user starts a pledge by clicking on the notification, the application records the user's identification number, and we are able to track this donation. We can then distinguish the direct pledges of the original adopters and the network pledges by their contacts. A simple way to compute the network effect is thus given by:

$$
\text { Network effect }=\frac{\text { Network pledges }}{\text { Direct pledges }} \text {. }
$$

Out of a total of 3,461 pledges, the direct pledges were 3,287, the estimated network effect $\frac{3,461-3,287}{3287}=\frac{174}{3287}=5.3 \%$. If we only consider the pledges that were processed and paid to the charitable organizations, the network effect is 5.1\%. These figures are shown in Table 5, overall and by charity. There is, again, heterogeneity across charities. For example, the American Red Cross has a network effect of 3.3\%, while PETA's pledges imply a network effect of $13.6 \%$.

The magnitudes of the network effects are similar for pledges broadcasted in Facebook and Twitter. ${ }^{14}$ On average, regular pledges and donations are higher than network-generated ones, although the median values are closer to each other. We also measured the network effects in terms of amount pledged and donated (Table 6). The users pledged a total of $\$ 197,333$, and $\$ 9,059$ were generated through the broadcasting feature (Panel A). This implies a network effect of $4.8 \%$ for the amount pledged. There is heterogeneity across the charitable organizations: while 1736 Family Crisis Center obtains has a network effect of 21.6\%, the pledges for American Red Cross consist of a 2.7\% network effect. In Panel B of Table 6 we consider the amount actually donated by the users. The total amount donated through the network is $\$ 2,956$, over a total of $\$ 80,913$, implying a $3.8 \%$ network effect, again with substantial heterogeneity across charities.

In Table 7, we report results from linear regression analyses of the relationship between broadcasting one's pledge and network pledges. The unit of observation is a pledge, and the outcome variable is equal to 1 if the pledge generated a network pledge (i.e., a pledge by one of the original user's Facebook friends or Twitter followers), and 0 otherwise. There is a positive and statistically significant correlation between broadcasting and network pledges being generated, and the magnitude and statistical significance of the estimated coefficient are robust to inclusion of charity and user fixed effects.

Although these findings are consistent with the presence of a network effect in charitable giving, we worry about several identification challenges that may affect the estimates and their interpretation. In

\footnotetext{
${ }^{14}$ The raw network effects were $16 \%$ for pledges made through Twitter Proxy (i.e., pledges to donate through the Twitter updates of another person), and 30\% for those through Twitter Tags (i.e., pledges to donate through a specific "hashtag"). However, there were only 204 pledges made through these channels. Therefore, we do not focus on them in this paper.
} 
particular, the broadcast feature of the application is a decision variable of the user. To the extent that social networks in Facebook and Twitter display homophily, user who broadcast their activity might be those with contacts who are more responsive, or they may even decide to broadcast to a selected group of individuals, e.g. the ones that are more likely to donate. ${ }^{15}$ This would confound the interpretation of the social multiplier effect. In addition to the endogeneity of the broadcast, users in the same social circles are exposed to similar events and influences that make them behave similarly; for example, fundraising campaigns and natural disasters may influence the volume of new pledges, and could change the magnitude of network effects in either direction. These empirical challenges cannot be addressed using the HA database. For this reason, we turn to an experimental design where we have clean control and treatment groups: the treated users will have the broadcast feature turned on, automatically broadcasting to all of their Facebook friends; the control group will not have any broadcasting opportunity. By randomizing this feature, we generate exogenous variation among users, and we can thus limit the identification problems discussed above.

\section{Field Experiment}

In collaboration with HA, we conducted a field experiment where users were invited to donate to Heifer International (http://www.heifer.org/), a charity whose mission is "to end poverty and hunger." ${ }^{16}$ We chose to work with only one charity to decrease the costs of coordination. Heifer is a relatively small charity with fast decision-making processes, which allowed us to obtain immediate feedback on the marketing campaign, and flexibly change it so we could experiment with different strategies. In addition, allowing the users to choose the charity would make the identification of social contagion more challenging even within a randomized controlled framework. ${ }^{17}$

\subsection{Design}

Figure 3 shows the HA Pledge page for Heifer International as seen by the users in our experiment. The experiment started with a marketing campaign on Facebook, with a mix of sponsored stories and ads that

\footnotetext{
${ }^{15}$ The application allows a general broadcast, to all Facebook friends, or a selected broadcast, where the users may indicate some of his friends as recipients of the initial broadcast and the follow-up messages during the pledge.

${ }^{16}$ Heifer provides domesticated animals and training to families, to improve their nutrition and generate income in a sustainable way. The family that receives the gift agrees to donate the offspring of the animal to another family in need. The animals are a source of both food and income. Milk from cows and goats, eggs from chicken, and honey from bees can be shared in the community or sold in the marketplace. The additional income and the training promote new opportunities for the creation of entrepreneurial activities, co-ops, or community savings groups.

${ }^{17}$ Testing whether the identity and the mission of the charity influence the initial recruitment and the viral diffusion of the donations is, of course, also an interesting research question. However, this test would require a more sophisticated design to enable the researchers to control for the charity quality and user base. We plan to explore these issues in future research.
} 
asked users to donate to Heifer International using the HA application. If a user clicked on the ad or sponsored story, she was re-directed to the webpage of Heifer International on the HA website.

The design consisted of randomly turning on and off the broadcasting feature of the application (in Figure 1B, the checkbox "Spread the word!"). Thus we have two conditions:

- C1: Broadcasting "off." Any donation activity is private to the individual user.

- C2: Broadcasting "on." Any donation activity is automatically notified to all of the user's contacts.

Figure $1 \mathrm{~B}$ shows the details of the HA viral features on the pledge webpage. Our intervention randomized the availability of the "Spread the word!" option at the time of pledging. Treated users automatically broadcasted their donation activity, while control users did not have that option. We then tracked the donation activity of the user and the donation activity of her contacts, if any. If a contact of the initial user started a new pledge with HA, we were able to track her activity, and link it to the initial user's activity. The comparison of the donation activity for the list of contacts in the two experimental conditions allows us to determine the presence, if any, of a causal link from the broadcasting feature of the application being turned on, to the number of donors and the amount pledged to Heifer International.

The major advantage of our design is that it allows us to track the diffusion starting from a set of seeding nodes, i.e. the initial users. The randomization provides the exogenous variation necessary to estimate causal effects of the broadcasting feature of the application. The use of the application is crucial to track the diffusion; we would not be able to track the social contagion without the initial users' friends lists, which is something that HA does, whereas the charities do not normally do this A limitation of our setting is that we cannot obtain data on individuals who do not install the application and pledge some money to the charity. So, for example, we cannot observe users' friends' characteristics until they become users of the HA application. This is due to the legal requirements of the application, which cannot collect data from the users' Facebook profiles without the users' permission (see also Aral and Walker 2011). As a consequence, we cannot track those friends' "likes," "shares," etc. An alternative design would collect the entire network and individual characteristics before the randomization, and follow the behavior of all the potential users (Banerjee et al. 2012). However, in online social networks, we would need to collect the entire universe of users.

\subsection{Implementation and Results}

The initial recruitment of the participants is crucial and proved to be challenging in our experiment. We relied on a mix of Facebook ads and sponsored stories, in collaboration and coordination with HA and Heifer International. The campaign was executed in three stages. The first stage started on June 7, 2012 with the sponsored story showed in Figure 5A, and a Facebook ad which mimicked the sponsored story. Our target audience for the campaign was the U.S. population 18-65 years old. 
During the first week (6/7-6/13), the sponsored story, which reached more than 484,000 Facebook users, was "liked" by 254 people, "shared" by 34, and prompted 42 comments on the Heifer Facebook page. 611 users clicked on the link, to be re-directed to the HA page. The ads were ineffective in terms of number of installations and pledges: with a total reach of 2,860 and 1,354 respectively, they generated only one click. This first campaign thus generated only three new Facebook pledges. In the second stage, started on June 22, 2012, we used a similar sponsored story and ads (Figure 5B), but increased the bid per click, which would give the ads greater visibility. The second campaign reached a significantly higher number of Facebook users: the total reach for the sponsored story was 3,742,000, with a total of more than 9 million impressions in 10 days. The story received 1,512 "likes," generated 164 comments, and was shared by 236 Facebook users. The total number of clicks was 4,859. Yet the ads generated in total only 235 clicks, even though the number of impressions was beyond 1 million. Overall, the second campaign generated an additional 19 pledges: 15 Facebook pledges, and 4 Twitter pledges. Thus, the first two stages of the campaign generated a total of 18 usable Facebook pledges (and 4 Twitter pledges). In the third stage, started on July 27, 2012, we offered to match the pledge of initial users with a \$5 donation (Figure 5C). This is a common scheme, used by many charitable organizations to promote donations, and has been found to increase not only the revenue per solicitation, but also the response rate (Karlan and List, 2007). Specifically, for each user's pledge, an extra $\$ 5$ would be given to Heifer by an anonymous "generous donor." The third campaign lasted two weeks, and only 7 additional Facebook pledges were made. The time series of likes, shares, and comments are shown in Figure 6 for the period that includes our marketing activity (February-November 2012). The red vertical dashed lines represent the dates of the sponsored story publications: we observe several spikes of activity that correspond to our campaign's initial dates, especially during the second wave. Descriptive details on the outcomes of our three promotional campaigns are displayed in Table 8.

Overall, our campaigns generated 30 pledges. However, some of these users deleted their pledge after a few days, or were inactive, and some were Twitter users. We focus here on the 25 "usable" Facebook pledges. These were the initial users from whom we tracked the diffusion: 13 initial users were randomly assigned to treatment group - broadcasting "on,", and 12 were assigned to the control group broadcasting "off." The former group had a total of 2,275 friends, and the latter 1,897 friends. Table 9A reports descriptive statistics for the 25 Facebook users, and the results of the experiment. ${ }^{18}$ Of these 25 users, 22 were females and only 3 males. Most pledges were based on the default HA pledge (maximum

\footnotetext{
${ }^{18}$ Some profiles are not entirely public, because users do not make their profile information publicly available, and the application can legally collect data from public profiles only. For some users, we have hometown, location, and several other controls.
} 
amount \$20, 1-month period). The rate per Facebook update was quite variable. There are no substantial differences between the control and treatment group in terms of observable actions and characteristics.

The campaigns, therefore, generated interest and attention, as can be inferred by the fact that the stories were liked, shared, and commented upon by a non-negligible share of users (see Figure 7 and Table 8). However, most of the attention is expressed in the least costly way, i.e. simply by liking a story, followed by sharing, and then by commenting, which is a little more costly in terms of time and effort. However, but somewhat consistently with the decline of expressions of interest as they become more costly, the actual donation rates were very low. In addition, social contagion did not take place; of the 4,172 friends of our initial users, none pledged to Heifer International. Recall that the HA application automatically sends several broadcasting messages of the donation activity to the friends of the treated group (one at the moment of the initial pledge, one after few days, one after the user reached half of the total amount pledged, and one at the end of the period). Even though this reinforcement mechanism was in place, there were no additional pledges generated through the network of the treated users. One might be concerned that donors could have donated to the charity directly, i.e. without going through the HA app. However, communications with Heifer International revealed that the charity did not experience higher donation rates in the weeks after our promotional campaigns were launched, which indicates that the lack of an effect of our campaigns on donations through HA is genuine.

\section{Survey Experiment}

Our field experiment and, to some extent, the historical HA data, shows that actually making a donation on this platform is relatively rare and, it can be inferred, considered more costly than other forms of less active engagement, such as "likes" and comments. To further investigate the potential sources of the small donation rates that we found, we ran a computerized, online survey experiment where respondents were asked about their willingness to make a small donation to a charity. We asked 1,605 U.S.-based participants on Amazon Mechanical Turk (MTurk) to state their willingness to donate $\$ 5$ to charity if they were given $\$ 10$. We manipulated the question to study the impact on the willingness to donate of the identity of the charity, the presence of processing fees, and the presence of an intermediary between the donor and the charity. The presence of a fee and an intermediary were prominent features of HA's business model, whereas specifying a charity was somewhat specific to our field experiment (HA allowed donors to choose from a variety of charities).

\subsection{Design}

We presented the key survey questions to the respondents using the Item Count Technique (ITC) to our survey. The ITC is based on not asking a question directly (e.g., "If you were given $\$ 10$, would you 
donate $\$ 5$ to charity?"); instead, respondents report the number of descriptive phrases, from a list that they are given, which they believe apply to themselves. A control group is given a list of $\mathrm{N}$ "neutral" phrases (i.e., non-sensitive in nature), whereas the treatment group is given $\mathrm{N}+1$ sentences, of which $\mathrm{N}$ are the same as for the control, and the additional item is the one of main interest. Thus the researcher cannot infer if a given respondent answered positively or negatively to a given item; only the total number of items that apply to an individual is identified. This preserves the privacy of the respondents and, together with the anonymity of the online survey, allays the concern that they might give what they perceive to be the "socially correct" answer. ${ }^{19,20}$ In our case, the hypothetical framework might lead to an upward bias if most respondents believe that donating $\$ 5$ is more socially acceptable and is what the researchers expect. With subjects assigned randomly to various experimental conditions, and a large enough sample size, the difference in the average counts between treatment and control gives an estimate of the share of individuals in the treatment group to which the phrase of interest applies (Coffman et al. 2013, Miller 1984). The key question in our survey asked the respondents to indicate how many of the listed statements applied to them. In the control condition, four statements were reported, and in the various treatment conditions, the fifth statement was a sentence indicating that, if the respondent was to receive $\$ 10$, he or she would make a $\$ 5$ charitable donation.

The treatment conditions were defined by the presence and the wording of the fifth sentence assigned to the subjects (Table 10), with the aim of identifying potential determinants of the donation rates, and in particular, given the findings from the experiment, to identify factors that drive donation rates down.

- Presence of a fee. First, the presence of a processing fee might inhibit donations, regardless of the identity of the receiving organizations. Some studies and the popular press alike, for example, point to "overhead" costs as driving potential donors away from supporting a given cause or organization, as opposed to when the entire amount donated is believed to be fully used for the cause (Ellis 2013; Roderick Williams 2007; Rooney and Frederick 2007). We set out to test for this possibility by providing three additional versions of the main sentence on donating $\$ 5$, where we indicated, for each of the three charity options described above, that a processing fee would be applied. We set the fee to be $8.25 \%$ of the donated amount, to match the fee actually charged by HA.

\footnotetext{
${ }^{19}$ Hypothetical questions, especially on topics for which respondents may be concerned about social desirability, might not be a good proxy for actual behavior. Researchers have been particularly aware of this issue in areas such as discrimination (Ayres and Siegelman 1995; Bertrand and Mullainathan 2004; Milkman et al. 2012), sexual orientation (Chandra et al. 2011; Coffman et al. 2013), and, more directly related to our topic, altruistic behavior (Lacetera et al. 2013).

${ }^{20}$ A further condition for assuring that single answers cannot be identified and attributed to a respondent is that the listed items are such that not everybody believes that they apply or do not apply to them. This is achieved, for example, by choosing items that are somewhat "negatively correlated" among each other, such that if a respondent believes that one or two of them apply to her, then it is likely that the others do not. This is the case in our survey, where very few respondents had a count of zero or 4 (in the control) or 5 (in the treatment conditions).
} 
- Presence of an intermediary. Second, a fee might have a negative effect on the willingness to donate if it is collected and used by a third, intermediary organization, as in the business model of HA. Potential donors might be discouraged from contributing if they perceived an increased "distance" between their action and the ultimate receiver. Coffman (2013), on the other hand, finds that the presence of an intermediary reduces differences across charities by making donations less dependent on the quality of the charity. To test the impact of involving an intermediary, we included a condition that specified that the $8.25 \%$ fee associated with donating $\$ 5$ to the charity would go to an (unspecified) intermediary.

- Identity and salience of the charity. Third, we wanted to investigate whether donation rates were affected by the salience of the receiver. Especially in an environment where information is added at a fast pace (such as Facebook), it is plausible that the attention of a user to each single piece of information is limited. Low salience may be due to the type of message ${ }^{21}$ or the identity of the receiver. This latter case might occur, as for example is the case for Heifer International, if the charitable organization is not widely known (Heifer had received only a few pledges in HA prior to our field experiment). In the key treatment sentence, we therefore assigned, as the organization that would hypothetically receive \$5 from the respondent, one between Heifer International, the American Red Cross (ARC), or a generic "charity of choice." We chose the ARC because of its wide popularity (including among HA donors, as seen in Table 1), in contrast to the more limited popularity of Heifer (in general and also in terms of donation activity via HA, as discussed above), and we also added a "choice" option to test whether the indication itself of a precise charity would have an impact (HA does in fact offer a wide range of charities for users to support). ${ }^{22}$ Table 9 reports the nine versions of the sentence that constitute our treatment conditions. ${ }^{23}$

\subsection{Data and findings}

Of the 2,244 responses, 219 were incomplete and thus discarded. Moreover, 250 individuals took the survey twice, and we excluded these cases too. This left us with 1,605 unique respondents. Summary statistics on the demographic and attitudinal questions included in our survey (and common to all treatments) are reported in Tables 11 and 12. The sample was well-balanced by conditions, and therefore the randomization was successful. Moreover, the characteristics of our sample are comparable to those in Coffman et al. (2013). This reassures us that our respondents are not an unusual sample of MTurk respondents. The median respondent is male, under 30 years old, white, is not married and has no

\footnotetext{
${ }^{21}$ Tucker (2011), for example, shows that the virality and persuasiveness of an online video may be negatively correlated.

${ }^{22}$ Respondents in the "charity of choice" condition were not asked to actually indicate one specific recipient, but could just think of the donation going to their hypothetical choice.

${ }^{23}$ Within each condition, a subject was randomly assigned to two different orderings of the four or five items, in order to mitigate any effect that the position of a particular item, and especially the one of our interest, might have on responses.
} 
children, has a monthly income of $\$ 1,500$ or less, has volunteered over the previous two years, and has some college education. About 50\% of the respondents are employees, $15 \%$ are self-employed, and 15\% are students. Most are atheist or agnostic and have liberal political views.

We estimate the share of individuals who would be willing to donate \$5 through the following model:

$$
Y_{i}=\alpha+\sum_{j=1}^{T} \beta_{j} \tau_{j}+\gamma X_{i}+\varepsilon_{i},
$$

where $Y_{i}$, the outcome variable, is the count of statements that subject i indicated to apply to him or her; thus the variables takes integer values between 0 and 4 in the control condition, and between 0 and 5 in each of the treatment conditions. The average count for the control condition is expressed by the OLS estimate of the parameter $\alpha$. The indicators $\tau_{j}$ assume a value of one if a subject $i$ is assigned to treatment $j$, and zero otherwise. The estimates of the parameters $\beta_{j}$ represent the differences in average response counts between the control and a given treatment condition $j$. We define the treatments at different levels of aggregation. First, we combine the nine conditions into three groups as given by the indication of the three different charities: ARC, Heifer, and a charity of choice. Second, we distinguish between versions of the treatment sentence indicating or not indicating the presence of a fee (with or without the indication of an intermediary). Third, limited to the cases where a fee was indicated, we separate the cases where the presence of an intermediary was not indicated and the cases where it was indicated. Finally, we also run the regression with the full set of disaggregated conditions (equivalently, we can think of these as interactions among the more aggregated conditions). The vector $X_{i}$ includes the control variables from the other responses to the survey.

The estimated donation rate in all conditions is significantly greater than zero: on average, mean response counts over all treatment conditions are 2.48 over 2.13 for the controls, implying an average donation rate of $35 \%$. This overall willingness to donate may be due to the structure of the experiment, despite our attempt to mitigate the social desirability (upward) bias. For the objective of this study, however, the interesting margins are the differences among the various treatments. ${ }^{24}$ Evidence of these differences is reported graphically in Figure 8, whereas the regression results are in Table 13.

A first finding is that the presence of a fee inhibits donations by about 15 percentage points (or about $33 \%$ of the effect with no fees), as can be seen in panel A of Figure 12 and Columns 1 and 2 of table $12 .^{25}$

\footnotetext{
${ }^{24}$ A focus on the differences among conditions also alleviates concerns about the external validity of the survey because the sample characteristics may vary from those of a broader population.

${ }^{25}$ In column 2 (as well as in columns 4, 6, and 8) the reported estimates come from a model that includes the full set of control variables (entered as categorical dummies) as derived from the survey. Because these variables were balanced across conditions thanks to the randomization and the relatively large sample size per condition, the inclusion of these variables in the regressions never affects the main estimates of interest.
} 
Second, a further negative effect on donation rates arises when the fee is presented to pertain to an intermediary organization; we observe a decline of 11 percentage points as compared to a scenario with a fee, but where there is no mention of an intermediary (Figure 8 Panel B, and columns 3-4 of Table 13).

Third, the identity of the charity does affect donation rates; in particular, the fact that naming the ARC leads to almost twice a high stated donation rates as mentioning Heifer (40\% vs. 23\%; Panel A of Figure 8 and columns 1 and 2 of Table 13) is consistent with lower recognizability of the charity limiting the subjects' willingness to contribute to it. Interestingly, leaving the charity choice open led about 38\% of respondents to express willingness to donate, very similar to the level for ARC.

Columns 7-8 of Table 13 show that the presence of a fee, and, in addition, the presence of an intermediary, depresses the willingness to donate, and especially so when the charity mentioned is Heifer. Patterns are slightly different for the charity of choice, with the presence of a fee and an intermediary depressing donations significantly, but the presence of a fee per se actually leading to higher donation rates compared to when the fee is absent, although the difference is not statistically significant.

Overall, the findings are consistent with the various hypotheses that we stated above: the salience or recognizability of a charity or cause, the presence of a fee, and the involvement of the intermediary all contribute to affect donation rates; in particular, the limited recognizability of a charity, and the fact that a fee is charged through the involvement of a third party, all play against obtaining high donation rates.

\section{Conclusion}

The observational and experimental data that we collected and analyzed showed a limited engagement of users through actual donations. In addition, although the historical data from application adoption and donation activities for HA were consistent with the presence of social contagion and network effects in charitable giving, our field experiment generated very few pledges that, in turn, did not lead to any further donations by the user's contacts. The survey experiment, finally, implies that the presence of fees, especially if administered through an intermediary, as well as the limited salience of a charity, may all contribute to inhibit the willingness to donate.

Overall, our findings are consistent with the presence of behaviors and phenomena such as "slacktivism" or "illusion of activism" (Kristofferson et al. forthcoming; Lewis et al. 2014). At least for now, therefore, people may see social networks as essentially free platforms for personal exchanges, and much less as vehicles for costly activities. Moreover, although social contagion through online social networks may occur when free activities are concerned, even relatively small costs may discourage individuals or shield them from peer pressure.

An implication of our findings for charitable organizations is that they might need to be direct when asking for actual monetary support online so as to limit the perception that individuals can be active with 
substitute, "costless" activities (such as a "like" or "share"). ${ }^{26}$ Limiting the reliance on administrative fees as well as the involvement of third parties may also boost the willingness to contribute; for example, some charitable organizations with a Facebook page are opting for receiving donations directly on their Facebook account, by introducing a "Donate" button on their page. The charity receives $100 \%$ of the donation, without overheads or fees, and Facebook guarantees the transaction. ${ }^{27}$ In addition, limited visibility is hard to overcome with online campaigns, which appear to favor large, established organizations. Consistent with previous studies showing that networks on social media are largely based on homophily (Lewis et al. 2011), the different estimates of network effects (or lack thereof) in the observational and controlled experimental analyses imply that social contagion in online charitable giving may be limited or require additional effort by organizations.

More broadly, the results here provide some insights as of the motivations for charitable giving. In particular, the fact that, when cheaper but visible alternative form of support are present, individuals do use them much more frequently than offering actual monetary donations, is consistent with self or socialimage concerns being a factor that motivates giving.

A further contribution of our study, together with others that rely on increasingly available data from online platforms, is the use of multiple research methodologies, and in particular the combination of observational and experimental data. Empirical strategies that combine the richness and detail of historical data with the potential for clean identification of experiments will hopefully be employed in future studies to enhance our understanding of the phenomena described here and related ones. For example, Angrist (2013) stresses the importance of complementing observational evidence with randomized trials to assess the causal impact of peer and social spillover effects. Our exercise is in this spirit and in fact, consistent with Angrist's conclusion, we find very little, if any, causal evidence of genuine online social contagion in charitable giving.

\section{References}

Angrist, J., 2013: "The Perils of Peer Effects," NBER Working Paper 19774.

Angrist, J., and Pischke, S., 2009: Mostly Harmless Econometrics: An Empiricist's Companion, Princeton University Press.

Aral, S. and Walker D., 2011: "Creating Social Contagion through viral product design A Randomized Trial of Peer Influence in Networks," Management Science, 57, 9, 1623-39.

Ashraf, N., Bandiera, O., and Jack, K., 2012: "No Margin, No Mission?," working paper, CEPR.

Athey, S. and Gans, J., 2010: "The Impact of Targeting Technology on Advertising Markets and Media Competition," American Economic Review Papers and Proceedings, 100, 608-61.

Ayres, I. and Siegelman, P., 1995: "Race and Gender Discrimination in Bargaining for a New Car," American Economic Review, 85, 3, 304-21.

${ }^{26}$ See for example Castillo et al. (2014) for a study with direct peer-to-peer asking.

${ }^{27}$ http://newsroom.fb.com/news/2013/12/donate-to-nonprofits-through-facebook/ 
Banerjee, A., Chandrasekhar, A., Duflo, E. and Jackson, M.O., 2012: "The Diffusion of Microfinance," working paper, MIT.

Bapna, R. and Umyarov, A., 2014: "Do Your Online Friends Make You Pay? A Randomized Field Experiment in an Online Music Social Network," working paper.

Bergemann, D. and Bonatti, A., 2010: "Targeting in Advertising Markets: Implications for Offline versus Online Media," RAND Journal of Economics, 42, 3, 417-443.

Bertrand, M. and Mullainathan, S., 2004: "Are Emily and Greg More Employable Than Lakisha and Jamal? A Field Experiment on Labor Market Discrimination," American Economic Review, 94, 4, 991-1013.

Blackbaud, 2013, The 2012 Charitable Giving Report, Blackbaud, Inc., Charleston, SC.

Blake, T., Nosko C. and Tadelis, S., 2014: "Consumer Heterogeneity and Paid Search Effectiveness: A Large Scale Field Experiment”, working paper, UC Berkeley

Bryan, G., Karlan, D., and Nelson, S. (2010). "Commitment Devices," Annual Review of Economics, 2, 671-698.

Cameron, A. et al., 2013: "Social Media and Organ Donor Registration: The Facebook Effect," American Journal of Transplantation, 13, 8, 2059-2065.

Castillo, M., Petrie, R., and Wardell, C., "Fundraising through Online Social Networks: a Field Experiment on Peerto-Peer Solicitation", forthcoming, Journal of Public Economics, 2014.

Coady Diemar Partners, 2012: U.S. Digital Advertising.

Coffman, L., 2013: "Fundraising \& Information Overload: How Intermediation in Fundraising Reduces Donation Differences across Charities," working paper, Ohio State University.

Coffman, K., Coffman, L., and Ericson, K., 2013: "The Size of the LGBT Population and the Magnitude of AntiGay Sentiment are substantially Underestimated," working paper, Ohio State University.

DellaVigna, S., List, J. and Malmendier, U., 2012: "Testing for Altruism and Social Pressure in Charitable Giving," Quarterly Journal of Economics, 127, 1-56.

Ellis, B., 2013: "Where Your Donation Dollars Go," $\quad$ CNN Money, May 24 (http://money.cnn.com/2013/05/24/pf/donations-charities/).

eMarketer, 2013: " Ecommerce Sales Topped \$1 Trillion for First Time in 2012,", www.emerketer.com.

Goldfarb, A. and Tucker, C., 2011: "Search Engine Advertising: Channel Substitution when Pricing Ads to Context," Management Science, 57, 3, 458-70.

Jopson, B., 2013: "US Bricks-and-Mortar Retailers Seek Online Success," Financial Times, Dec. 27.

Karlan, D., and List, J., 2007: "Does Price Matter in Charitable Giving? Evidence from a Large-Scale Natural Field Experiment," American Economic Review, 97, 5 1774-1793.

Kim, L., 2012: "Google Display Network vs. Facebook Advertising," Wordstream (http://www.wordstream.com/blog/ws/2012/05/15/ipo-facebook-vs-google-display-advertising).

Kristofferson, K., White, K. and Peloza, J., forthcoming: "The Nature of Slacktivism: How the Social Observability of an Initial Act of Token Support Affects Subsequent Prosocial Action," Journal of Consumer Reseach.

Lacetera, N. and Macis, M., 2010: "Social Image Concerns and Prosocial Behavior: Field Evidence from a Nonlinear Incentive Scheme," Journal of Economic Behavior \& Organization, 76, 2, 225-37.

Lacetera, N., Macis, M. and Slonim, R., 2013: "Economic rewards to Motivate Blood Donations," Science, 340, 6135, 927-8.

Lewis, K., Gonzalez, M., and Kaufman, J., 2014: "Social Selection and Peer Influence in an Online Social Network," Proceedings of the National Academy of Sciences, 109:68-72.

Manchanda P., Xie, Y. and Youn, N., 2008: "The Role of Targeted Communication and Contagion in Product Adoption," Marketing Science, 27, 6, 961-976.

Milkman, K.L., Akinola, M. Chugh, D., 2012: "Temporal Distance and Discrimination: An Audit Study in Academia," Psychological Science, 23, 7, 710-17

Miller, J.D., 1984: A New Survey Technique for Studying Deviant Behavior," Ph.D. dissertation, George Washington University, 1984.

Moretti, E., 2011: "Social Learning and Peer Effects in Consumption: Evidence from Movie Sales," Review of Economic Studies, 78, 356-93. 
Nam, S., Manchanda, P. and Chintagunta, P., 2010: "The Effect of Signal Quality and Contiguous Word of Mouth on Customer Acquisition for a Video-On-Demand Service," Marketing Science, 29, 4, 690-700.

Roderick Williams, S., 2007: "Donor Preferences and Charitable Giving," International Journal of Educational Advancement, 7, 3, 176-89.

Rooney, P. and Frederick, H.K., 2007: "Paying for Overhead: A Study of the Impact of Foundations' Overhead Payment Policies on Educational and Human Service Organizations," working paper, Aspen Institute.

Shalizi, C.R., and Thomas, A.C., 2011: "Homophily and Contagion Are Generically Confounded in Observational Social Network Studies," Sociological Methods and Research, 40, 2, 211-39.

Shang, J. and Croson, R., 2009: "A Field Experiment in Charitable Contribution: The Impact of Social Information on the Voluntary Provision of Public Goods," Economic Journal, 119, 540, 1422-39.

Smith, SL, Windmeijer, F \& Wright, E.W., 2013, "Peer effects in charitable giving: Evidence from the (running) field," The Economic Journal.

Teixeira, T.S., 2014: "The Rising Cost of Consumer Attention: Why You Should Care, and What You Can Do about It," Harvard Business School Working Paper, No. 14-055.

Tucker, C., 2011: "Ad Virality and Ad Persuasiveness," working paper, MIT.

Tucker, C., 2012: "Social Advertising," working paper, MIT. 
Figure 1: Examples of Helpattack! Pledge Pages

Note: the figures have been edited to conceal users' identifiable information.

\section{A: Sample pledge page}

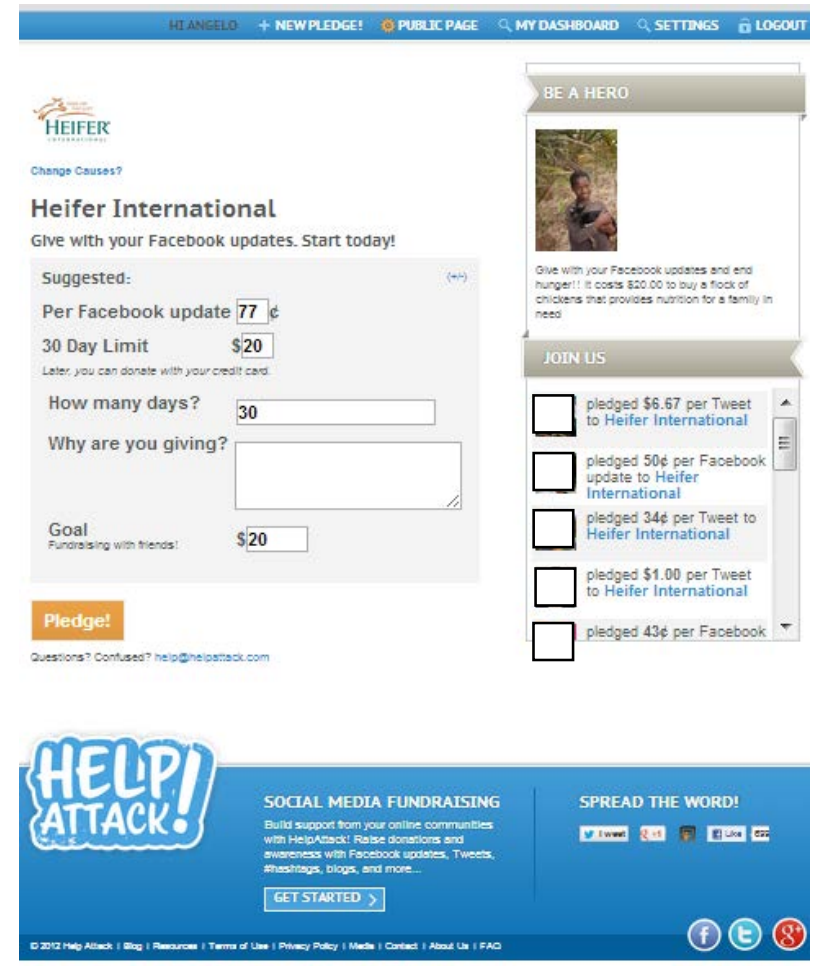

\section{B: Viral features - Details}

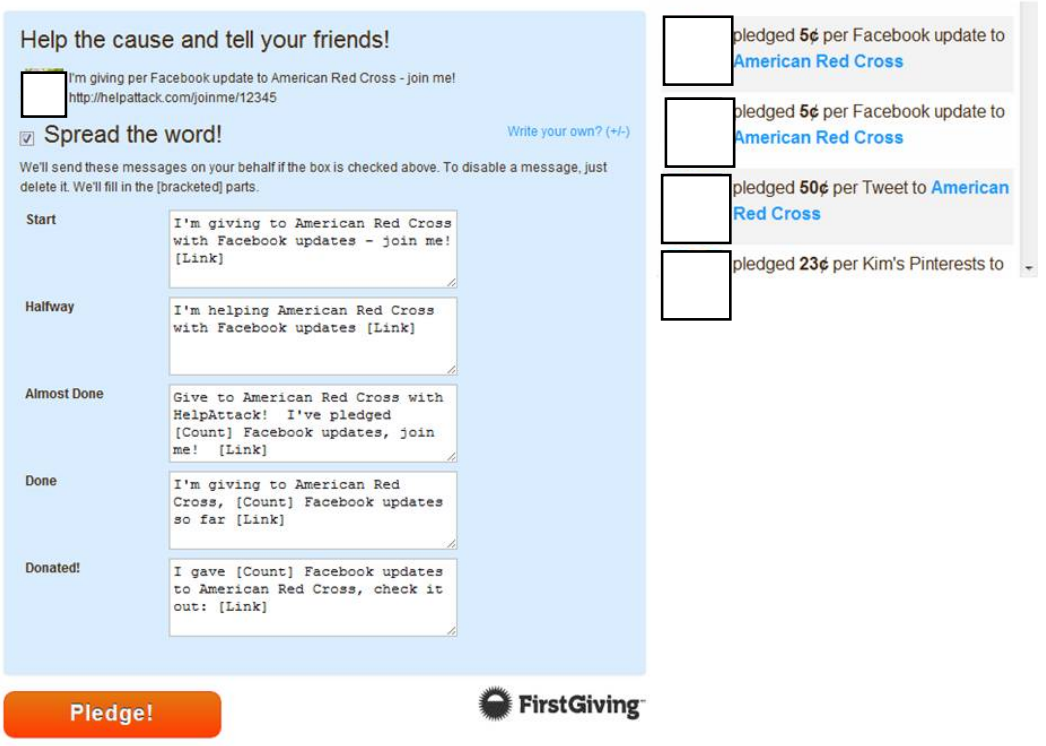




\section{C: Examples of broadcasted messages}
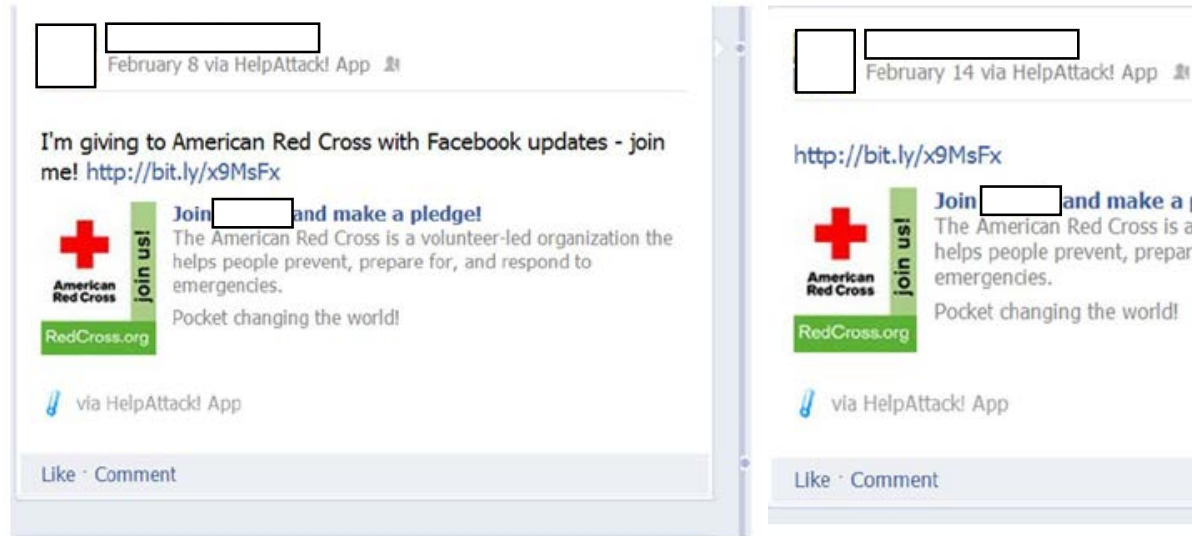

http://bit.ly/x9MsFx

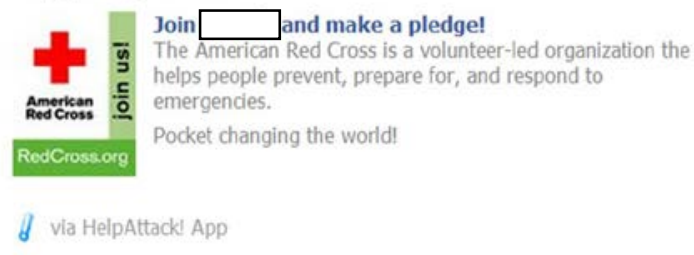

Like - Comment

Figure 2: New pledges for the American Red Cross, by starting date

The graph shows the number of pledges by starting date for the American Red Cross.

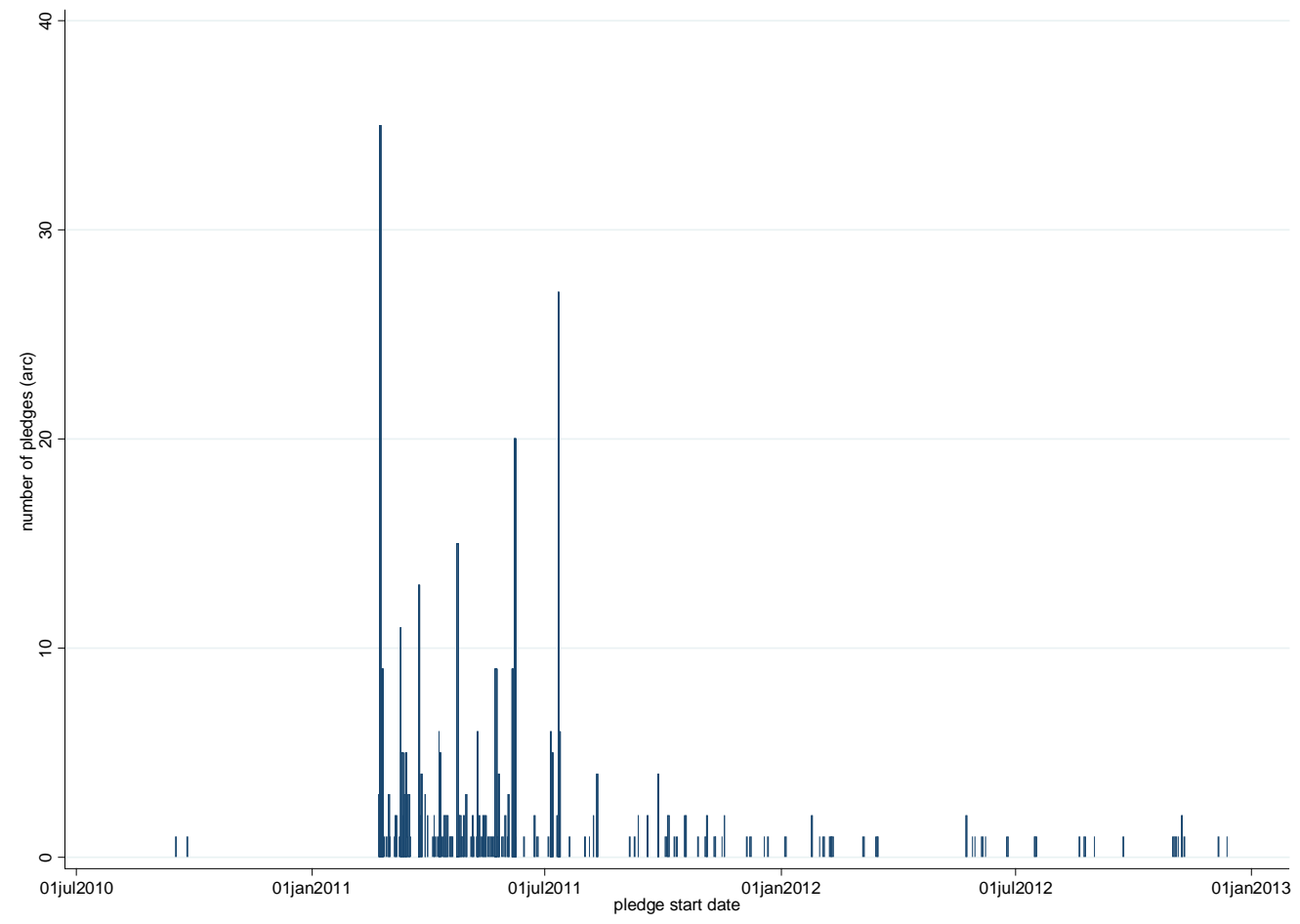




\section{Figure 3: Helpattack! Pledge page for Heifer International}

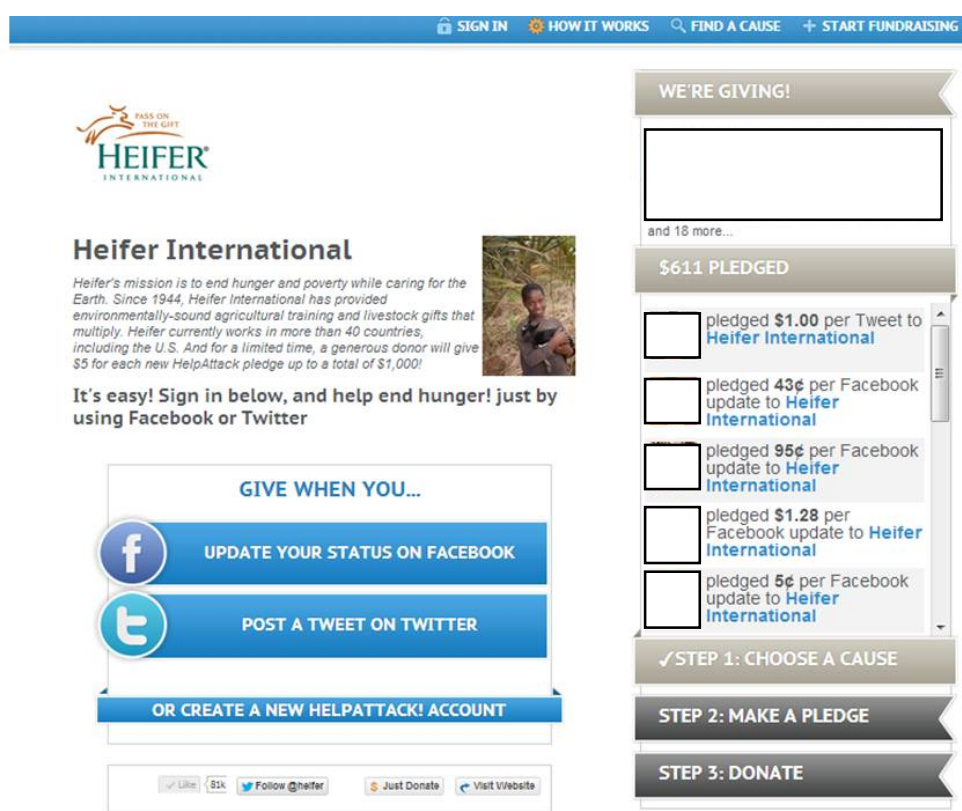

Figure 4: Experimental Design

The treated group of initial users broadcasts the information about the charity and the donation activity to their friends. The control group of initial users has the broadcasting feature of the application turned off.
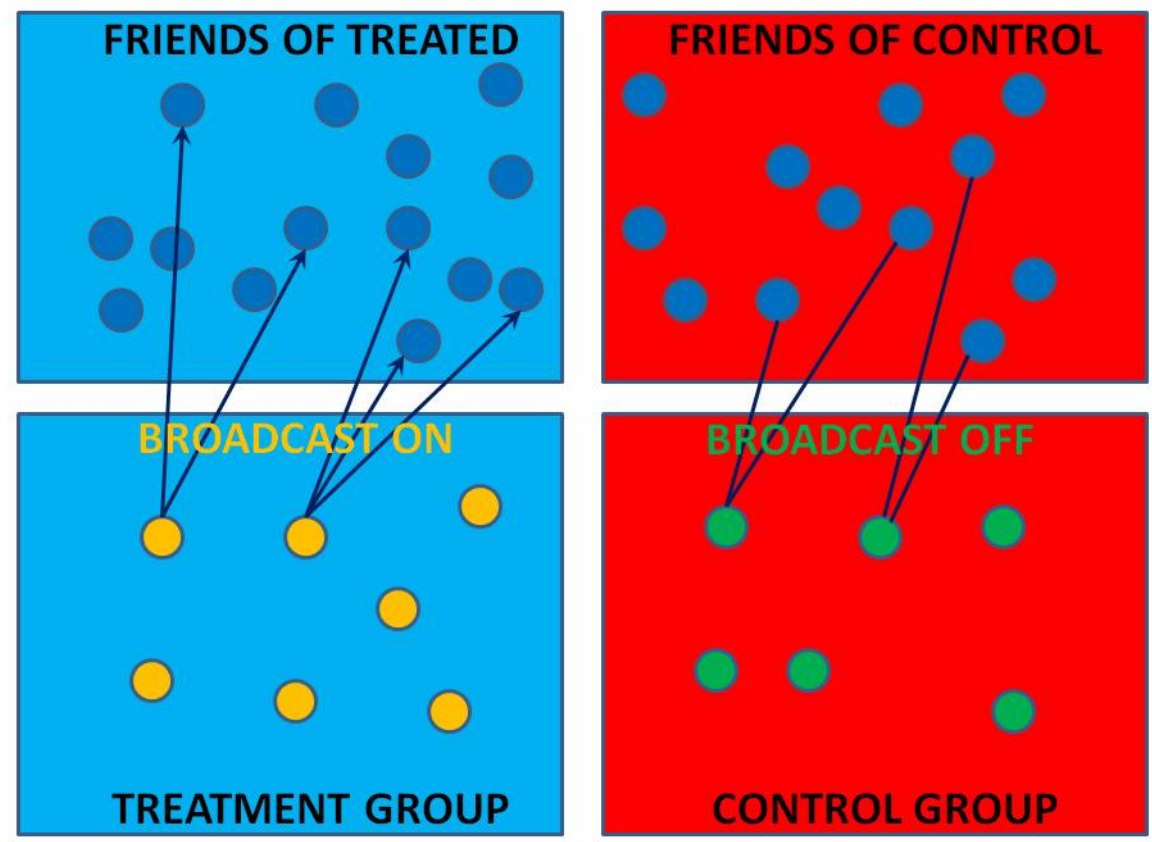


\section{Figure 5A: Sponsored story for campaign $\left(1^{\text {st }}\right.$ stage $)$}

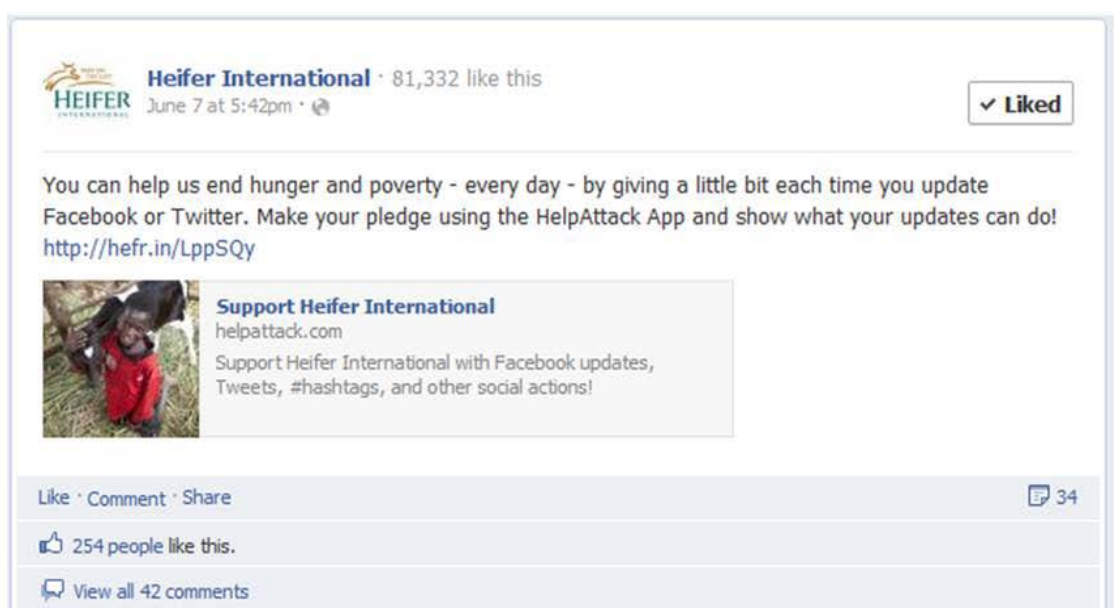

Figure 5B: Sponsored story for campaign $\left(2^{\text {nd }}\right.$ Stage $)$

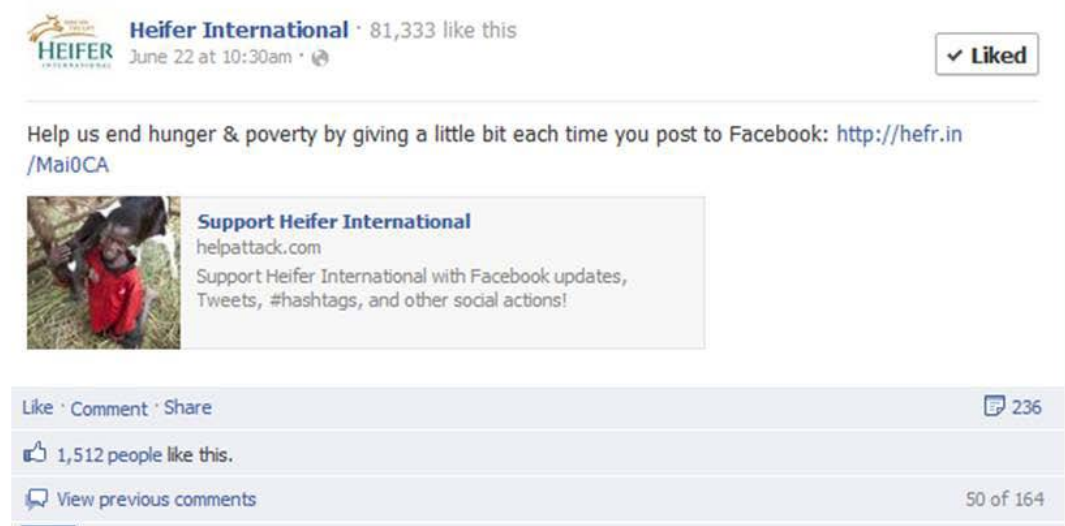

Figure 5C: Sponsored story for campaign $\left(3^{\text {rd }}\right.$ Stage $)$

Heifer International - 81,333 like this

HEIFER July 27 at $11: 23 \mathrm{pm} \cdot$ a $^{2}$

Help us end hunger: Give a little each time you post and your gift will be matched: $h$ ttp://hefr.in /04gbXV

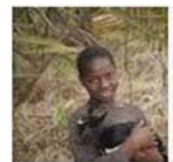

Support Heifer International

helpattack.com

Support Heifer with Facebook updates and other social

actions. For a limited time, a generous donor will give $\$ 5$ for

each new HelpAttack pledae...up to a total of $\$ 1,000$ !

Like - Comment Share

C3 243 people like this. 
Figure 6: Field Experiment - Likes, Shares and Comments on the Heifer International FB Page
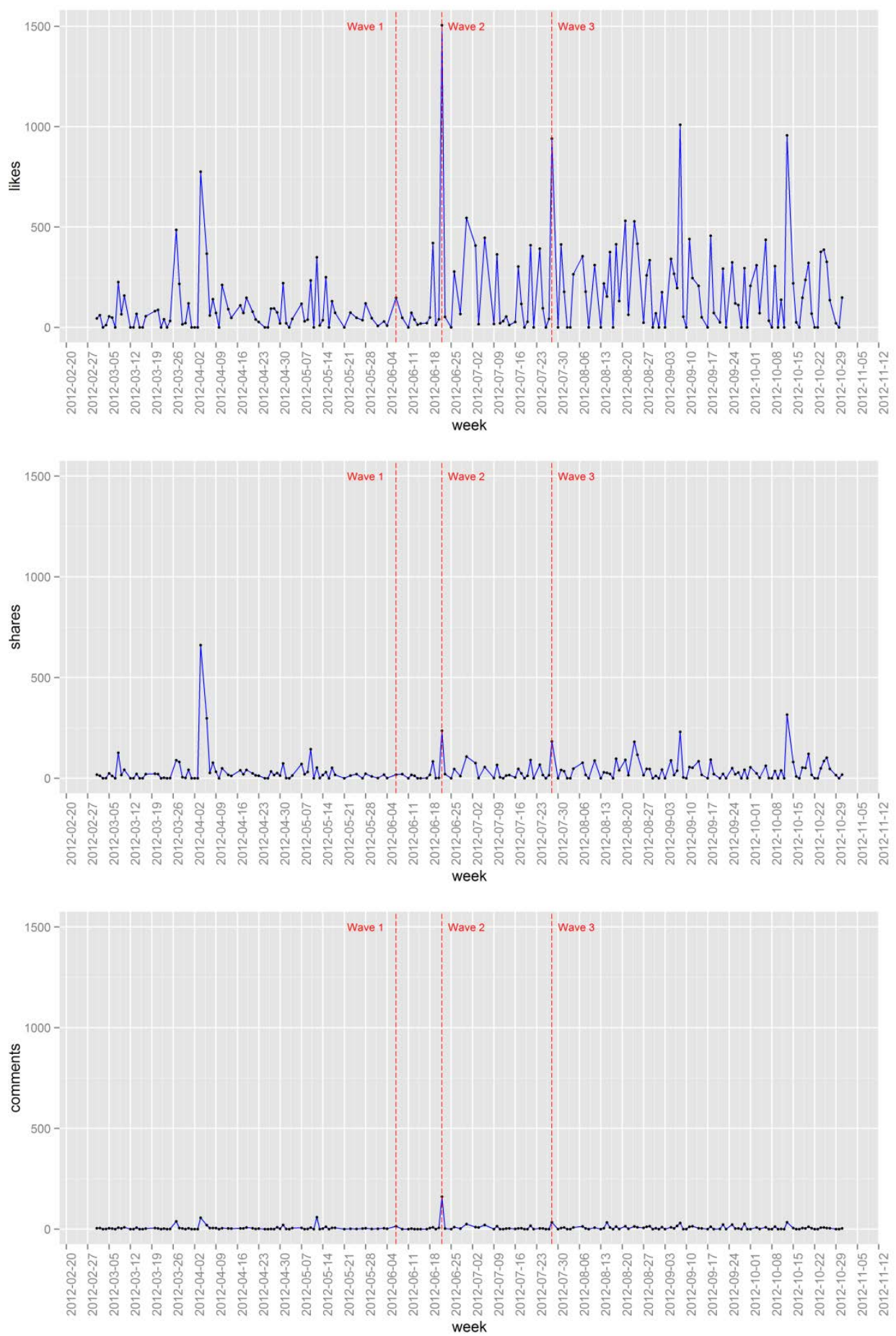
Figure 7: Field Experiment - Responses to the Sponsored Stories and Facebook Ads

This figure displays the reactions to the sponsored stories and Facebook ads that were part of our fieldexperimental intervention.

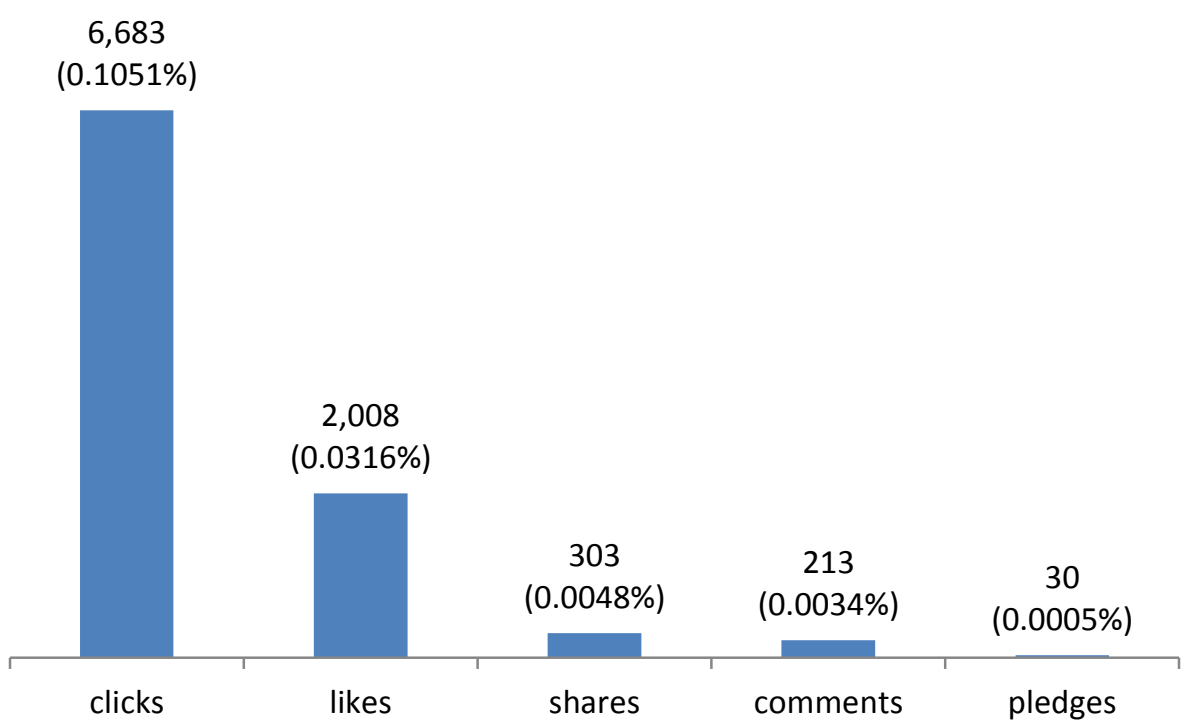


Figure 8: Survey experiment - Donation rates by charity, presence of a fee, and presence of an intermediary

The graphed values were obtained as differences between the average counts between the relevant treatment condition and the control in the main survey question. 95\% confidence intervals are also reported.

\section{A: By presence of a fee}

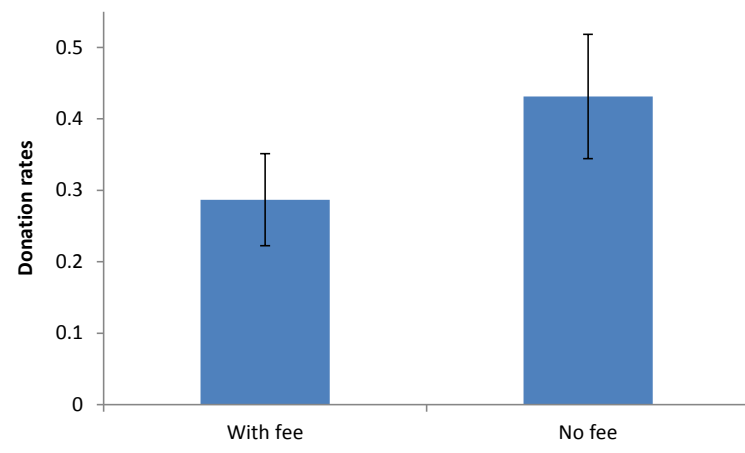

B: By presence of an intermediary, conditional on presence of a fee

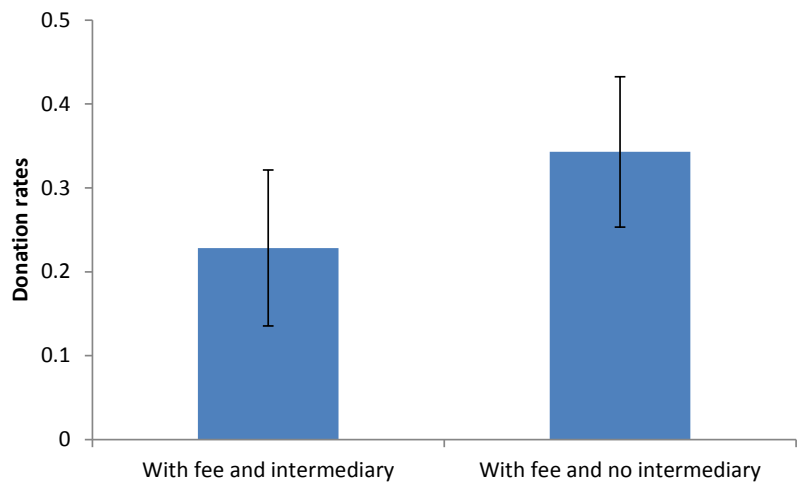

C: By charity

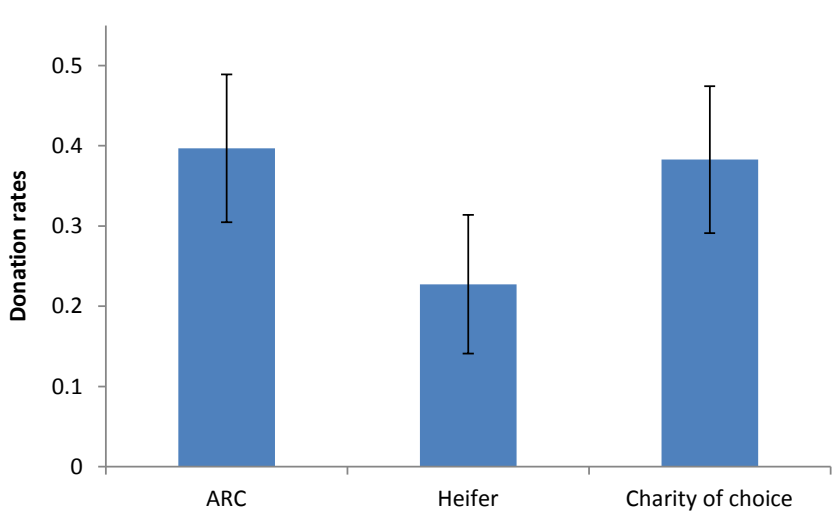


Table 1: Most popular charities on HelpAttack!, by status of the pledge.

The table shows the distribution of pledges by outcome, in total and for the most popular charities in the database, i.e. organizations with more than 50 pledges total. Fulfilled indicates pledges with a payment processed for (at least) the pledged amount; Partially fulfilled indicates pledges with a payment processed for an amount smaller than the amount pledged; Deleted indicates pledges that were deleted before being paid and that therefore did not result in an actual donation; Inactive pledges were started but there was no subsequent activity on the users' Facebook or Twitter profiles; Active pledges are the ones that were still open when the company was acquired in December 2012.

\begin{tabular}{|c|c|c|c|c|c|c|}
\hline Charity Name & $\begin{array}{c}\text { Total } \\
\text { N. of Pledges }\end{array}$ & $\begin{array}{c}\text { Fulfilled } \\
\%\end{array}$ & $\begin{array}{c}\text { Partially } \\
\text { fulfilled } \\
\%\end{array}$ & $\begin{array}{c}\text { Deleted } \\
\%\end{array}$ & $\begin{array}{c}\text { Inactive } \\
\%\end{array}$ & $\begin{array}{c}\text { Active } \\
\%\end{array}$ \\
\hline American Red Cross & 714 & 48.9 & 25.5 & 21.8 & 1.1 & 2.7 \\
\hline Best Friends Animal Society & 357 & 69.5 & 11.5 & 14.6 & 1.4 & 3.1 \\
\hline Fenix281 & 158 & 65.8 & 22.8 & 9.5 & 0.6 & 1.3 \\
\hline Mobile Loaves \& Fishes & 114 & 85.1 & 0 & 12.3 & 0 & 2.6 \\
\hline Arthritis Foundation & 98 & 73.5 & 0 & 14.3 & 0 & 12.2 \\
\hline NTEN: Nonprofit Technology Network & 72 & 66.7 & 0 & 20.8 & 2.8 & 9.7 \\
\hline U.S. Fund for UNICEF & 71 & 77.5 & 5.6 & 7 & 4.2 & 5.6 \\
\hline Autism Society Of America & 67 & 4.5 & 83.6 & 11.9 & 0 & 0 \\
\hline People For The Ethical Treatment of Animals (PETA) & 67 & 43.3 & 0 & 17.9 & 1.5 & 37.3 \\
\hline Lights. Camera. Help. & 59 & 91.5 & 0 & 8.5 & 0 & 0 \\
\hline Homes For Our Troops Inc & 53 & 7.5 & 79.2 & 13.2 & 0 & 0 \\
\hline 1736 Family Crisis Center & 51 & 19.6 & 66.7 & 11.8 & 0 & 2 \\
\hline Total & 3,461 & 64.1 & 12.5 & 15.8 & 1.4 & 6.2 \\
\hline
\end{tabular}


Table 2: Pledges and Donations - Summary statistics by medium

The table compares mean and median rate, amount pledged and amount donated of pledges made through Facebook and Twitter. Inactive and Active pledges were dropped.

\begin{tabular}{|c|c|c|c|c|c|}
\hline \multirow[b]{2}{*}{ Medium } & \multicolumn{5}{|c|}{ Pledges } \\
\hline & $\mathrm{N}$. & $\begin{array}{c}\text { mean } \\
\text { amount (\$) }\end{array}$ & $\begin{array}{c}\text { mean } \\
\text { rate (cents) }\end{array}$ & $\begin{array}{c}\text { median } \\
\text { amount (\$) }\end{array}$ & $\begin{array}{c}\text { median } \\
\text { rate (cents) }\end{array}$ \\
\hline Facebook & 1,366 & 65.5 & 94.3 & 40 & 50 \\
\hline Feed & 22 & 24.8 & 69.2 & 20 & 29 \\
\hline Twitter & 1,629 & 57.3 & 50.2 & 40 & 10 \\
\hline Twitter Proxy & 76 & 28.9 & 30.2 & 40 & 25 \\
\hline Twitter Tag & 103 & 31.2 & 22.1 & 20 & 10 \\
\hline \multirow[t]{3}{*}{ Total } & 3,196 & 59.1 & 67.8 & 40 & 25 \\
\hline & \multicolumn{5}{|c|}{ Donations } \\
\hline & $\mathrm{N}$. & $\begin{array}{c}\text { mean } \\
\text { amount }(\$)\end{array}$ & $\begin{array}{c}\text { mean } \\
\text { rate (cents) }\end{array}$ & $\begin{array}{c}\text { median } \\
\text { amount (\$) }\end{array}$ & $\begin{array}{c}\text { median } \\
\text { rate (cents) }\end{array}$ \\
\hline Facebook & 1,186 & 34.9 & 94.9 & 31.05 & 50 \\
\hline Feed & 3 & 12.0 & 34.3 & 11.73 & 23 \\
\hline Twitter & 1,367 & 27.1 & 48.8 & 20 & 10 \\
\hline Twitter Proxy & 32 & 16.6 & 22.3 & 15 & 25 \\
\hline Twitter Tag & 62 & 24.4 & 24.3 & 19.9 & 17.5 \\
\hline Total & 2,650 & 30.4 & 68.5 & 20 & 25 \\
\hline
\end{tabular}


Table 3: Pledges and Donations - Summary statistics by charity

The table compares mean and median rates, amount pledged and amount donated of all pledges, and separately for charities with more than 50 pledges (inactive and active pledges were not included).

\begin{tabular}{|c|c|c|c|c|c|}
\hline \multirow[b]{2}{*}{ Charity Name } & \multicolumn{5}{|c|}{ Pledges } \\
\hline & N. & $\begin{array}{c}\text { mean } \\
\text { amount (\$) }\end{array}$ & $\begin{array}{c}\text { mean } \\
\text { rate (cents) }\end{array}$ & $\begin{array}{c}\text { median } \\
\text { amount }(\$)\end{array}$ & $\begin{array}{c}\text { median } \\
\text { rate (cents) }\end{array}$ \\
\hline American Red Cross & 687 & 53.2 & 39.3 & 40 & 10 \\
\hline Best Friends Animal Society & 341 & 48.8 & 72.5 & 40 & 39 \\
\hline Fenix281 & 155 & 98.4 & 86.8 & 40 & 66 \\
\hline Mobile Loaves \& Fishes & 111 & 40.0 & 106.5 & 40 & 30 \\
\hline Arthritis Foundation & 86 & 38.1 & 67.8 & 40 & 26 \\
\hline Autism Society Of America & 67 & 39.1 & 68.7 & 40 & 69 \\
\hline U.S. Fund for UNICEF & 64 & 33.6 & 62.4 & 40 & 25 \\
\hline NTEN: Nonprofit Technology Network & 63 & 38.6 & 13.7 & 25 & 6 \\
\hline Lights. Camera. Help. & 59 & 79.5 & 30.0 & 40 & 25 \\
\hline Homes For Our Troops Inc & 53 & 44.5 & 75.0 & 40 & 75 \\
\hline 1736 Family Crisis Center & 50 & 97.1 & 151.2 & 40 & 69 \\
\hline People For The Ethical Treatment of Animals (PETA) & 41 & 24.0 & 77.3 & 20 & 13 \\
\hline \multirow[t]{3}{*}{ Total } & 3,197 & 59.1 & 67.8 & 40 & 25 \\
\hline & \multicolumn{5}{|c|}{ Donations } \\
\hline & N. & $\begin{array}{c}\text { mean } \\
\text { amount }(\$) \\
\end{array}$ & $\begin{array}{c}\text { mean } \\
\text { rate (cents) }\end{array}$ & $\begin{array}{c}\text { median } \\
\text { amount (\$) }\end{array}$ & $\begin{array}{c}\text { median } \\
\text { rate (cents) }\end{array}$ \\
\hline American Red Cross & 531 & 30.4 & 44.0 & 21.4 & 10 \\
\hline Best Friends Animal Society & 289 & 33.9 & 64.5 & 34.1 & 40 \\
\hline Fenix281 & 140 & 60.4 & 86.7 & 40 & 66 \\
\hline Mobile Loaves \& Fishes & 97 & 24.0 & 105.9 & 20 & 30 \\
\hline Arthritis Foundation & 72 & 29.1 & 74.5 & 20.75 & 26 \\
\hline Autism Society Of America & 59 & 39.0 & 68.5 & 40 & 69 \\
\hline U.S. Fund for UNICEF & 59 & 22.8 & 65.8 & 20.7 & 25 \\
\hline Lights. Camera. Help. & 54 & 21.9 & 26.5 & 20 & 25 \\
\hline NTEN: Nonprofit Technology Network & 48 & 19.2 & 11.6 & 18.79 & 7.5 \\
\hline Homes For Our Troops Inc & 46 & 40.4 & 75.7 & 40 & 75 \\
\hline 1736 Family Crisis Center & 44 & 66.8 & 163.6 & 40 & 69 \\
\hline People For The Ethical Treatment of Animals (PETA) & 29 & 18.5 & 95.0 & 20 & 7 \\
\hline Total & 2,650 & 30.4 & 68.5 & 20 & 25 \\
\hline
\end{tabular}


Table 4: Broadcasting and Donation Behavior: Regression Analysis

In Panel A, the dependent variable is the share of a pledge that was fulfilled, and in Panel B the dependent variable is equal to 1 if a pledge was deleted, and 0 otherwise. We present results from linear probability models. The unit of observation is a pledge. The sample excludes pledges that were "active" or "inactive" as of December 31, 2012. Robust standard errors are reported in parentheses.

\begin{tabular}{lcccc}
\hline $\begin{array}{l}\text { Panel A } \\
\text { Outcome variable }=\text { share of pledge fulfilled }\end{array}$ & \multicolumn{3}{l}{} \\
\hline & $(1)$ & $(2)$ & $(3)$ & $(4)$ \\
Pledge broadcasted & -0.0000 & $0.0711^{* * *}$ & 0.0220 & $0.0902^{* * *}$ \\
& $(0.0138)$ & $(0.0144)$ & $(0.0149)$ & $(0.0149)$ \\
Pledge length (days) & 0.0001 & $0.0009^{* * *}$ & 0.0002 & $0.0009^{* * *}$ \\
& $(0.0001)$ & $(0.0002)$ & $(0.0001)$ & $(0.0002)$ \\
Pledge amount (\$) & $-0.0003^{* * *}$ & $-0.0010^{* * *}$ & $-0.0007^{* * *}$ & $-0.0013^{* * *}$ \\
& $(0.0000)$ & $(0.0002)$ & $(0.0001)$ & $(0.0003)$ \\
N. past pledges & $-0.0030^{* * *}$ & $-0.0021^{* * *}$ & $-0.0028^{* * *}$ & $-0.0021^{* * *}$ \\
& $(0.0002)$ & $(0.0002)$ & $(0.0002)$ & $(0.0002)$ \\
\$ donated in the past & $0.0001^{* * *}$ & $-0.0000^{* * *}$ & $0.0000^{* * *}$ & $-0.0000^{* * *}$ \\
& $(0.0000)$ & $(0.0000)$ & $(0.0000)$ & $(0.0000)$ \\
User Fixed Effects & & & & $X$ \\
Charity Fixed Effects & & $\mathrm{X}$ & & $\mathrm{X}$ \\
& & & & \\
Observations & 3,196 & 3,196 & 3,196 & 3,196 \\
Adjusted R-squared & 0.106 & 0.225 & 0.465 & 0.490 \\
\hline
\end{tabular}

Panel B

Outcome variable $=1$ if the pledge was deleted, 0 otherwise

\begin{tabular}{lcccc}
\hline & $(1)$ & $(2)$ & $(3)$ & $(4)$ \\
Pledge broadcasted & $0.0289^{* *}$ & $-0.1035^{* * *}$ & $-0.0344^{* *}$ & $-0.1427^{* * *}$ \\
& $(0.0132)$ & $(0.0153)$ & $(0.0146)$ & $(0.0159)$ \\
Pledge length (days) & $-0.0002^{* *}$ & $-0.0003^{*}$ & $-0.0002^{*}$ & $-0.0003^{*}$ \\
& $(0.0001)$ & $(0.0002)$ & $(0.0001)$ & $(0.0002)$ \\
Pledge amount $(\$)$ & $0.0001^{* * *}$ & $0.0003^{*}$ & $0.0001^{* *}$ & 0.0002 \\
& $(0.0000)$ & $(0.0002)$ & $(0.0001)$ & $(0.0003)$ \\
N. past pledges & $0.0036^{* * *}$ & $0.0030^{* * *}$ & $0.0034^{* * *}$ & $0.0029^{* * *}$ \\
& $(0.0002)$ & $(0.0002)$ & $(0.0002)$ & $(0.0002)$ \\
\$ donated in the past & $-0.0001^{* * *}$ & $0.0000^{* * *}$ & $-0.0000^{* * *}$ & $0.0000^{* * *}$ \\
& $(0.0000)$ & $(0.0000)$ & $(0.0000)$ & $(0.0000)$ \\
User Fixed Effects & & & & $X$ \\
Charity Fixed Effects & & $\mathrm{X}$ & & $\mathrm{X}$ \\
& & & $\mathrm{X}$ & \\
Observations & 3,196 & 3,196 & 3,196 & 3,196 \\
Adjusted R-squared & 0.151 & 0.226 & 0.372 & 0.398 \\
\hline
\end{tabular}


Table 5: Network effects - Number of pledges and actual donations

The table shows the most popular charities and the "network effect" generated. The network effect was computed as (Network pledges)/(total pledges - network pledges) $=($ Total pledges-direct pledges) $/$ (total pledges - network pledges).

\begin{tabular}{|c|c|c|c|}
\hline \multirow[t]{2}{*}{ Charity Name } & \multicolumn{3}{|c|}{ Pledges } \\
\hline & Total & Network & $\begin{array}{c}\text { Network } \\
\text { Effect }\end{array}$ \\
\hline American Red Cross & 714 & 23 & $3.3 \%$ \\
\hline Best Friends Animal Society & 357 & 11 & $3.2 \%$ \\
\hline Fenix281 & 158 & 1 & $0.6 \%$ \\
\hline Mobile Loaves \& Fishes & 114 & 6 & $5.6 \%$ \\
\hline Arthritis Foundation & 98 & 4 & $4.3 \%$ \\
\hline NTEN: Nonprofit Technology Network & 72 & 7 & $10.8 \%$ \\
\hline U.S. Fund for UNICEF & 71 & 2 & $2.9 \%$ \\
\hline Autism Society Of America & 67 & 0 & $0.0 \%$ \\
\hline People For The Ethical Treatment of Animals (PETA) & 67 & 8 & $13.6 \%$ \\
\hline Lights. Camera. Help. & 59 & 3 & $5.4 \%$ \\
\hline Homes For Our Troops Inc & 53 & 1 & $1.9 \%$ \\
\hline 1736 Family Crisis Center & 51 & 2 & $4.1 \%$ \\
\hline \multirow[t]{3}{*}{ Total } & 3,461 & 174 & $5.3 \%$ \\
\hline & \multicolumn{3}{|c|}{ Donations } \\
\hline & Total & Network & $\begin{array}{c}\text { Network } \\
\text { Effect }\end{array}$ \\
\hline American Red Cross & 349 & 12 & $3.6 \%$ \\
\hline Best Friends Animal Society & 248 & 9 & $3.8 \%$ \\
\hline Fenix281 & 104 & 0 & $0.0 \%$ \\
\hline Mobile Loaves \& Fishes & 97 & 6 & $6.6 \%$ \\
\hline Arthritis Foundation & 72 & 2 & $2.9 \%$ \\
\hline NTEN: Nonprofit Technology Network & 48 & 3 & $6.7 \%$ \\
\hline U.S. Fund for UNICEF & 55 & 2 & $3.8 \%$ \\
\hline Autism Society Of America & 3 & 0 & $0.0 \%$ \\
\hline People For The Ethical Treatment of Animals (PETA) & 29 & 4 & $16.0 \%$ \\
\hline Lights. Camera. Help. & 54 & 3 & $5.9 \%$ \\
\hline Homes For Our Troops Inc & 4 & 0 & $0.0 \%$ \\
\hline 1736 Family Crisis Center & 10 & 1 & $11.1 \%$ \\
\hline Total & 2218 & 107 & $5.1 \%$ \\
\hline
\end{tabular}


Table 6: Network effects - Amounts donated and pledged

The table shows the most popular charities and the "network effect" generated in terms of money pledged (or donated). The network effect was computed as (Amount pledged by network)/(total amount pledged amount pledged by network) $=$ (Total amount pledged - Amount directly pledged) /(total amount pledged - amount pledged by network).

\begin{tabular}{lccc}
\hline Panel A & & & \\
\hline Charity Name & $\begin{array}{c}\text { Total amount } \\
\text { pledged }\end{array}$ & $\begin{array}{c}\text { Amount } \\
\text { pledged from } \\
\text { Network }\end{array}$ & $\begin{array}{c}\text { Network } \\
\text { Effect }\end{array}$ \\
American Red Cross & 37,470 & 990 & $2.7 \%$ \\
Best Friends Animal Society & 17,148 & 1,365 & $8.6 \%$ \\
Fenix281 & 15,365 & 40 & $0.3 \%$ \\
Mobile Loaves \& Fishes & 4,543 & 181 & $4.1 \%$ \\
Arthritis Foundation & 3,560 & 125 & $3.6 \%$ \\
NTEN: Nonprofit Technology Network & 2,677 & 165 & $6.6 \%$ \\
U.S. Fund for UNICEF & 2,317 & 65 & $2.9 \%$ \\
Autism Society Of America & 2,620 & & $0.0 \%$ \\
People For The Ethical Treatment of Animals (PETA) & 1,515 & 235 & $18.4 \%$ \\
Lights. Camera. Help. & 4,692 & 145 & $3.2 \%$ \\
Homes For Our Troops Inc & 2,360 & 40 & $1.7 \%$ \\
1736 Family Crisis Center & 5,856 & 1,039 & $21.6 \%$ \\
Total & 197,333 & 9,059 & $4.8 \%$ \\
\hline
\end{tabular}

Panel B

Charity Name

American Red Cross

Best Friends Animal Society

Fenix281

Mobile Loaves \& Fishes

Arthritis Foundation

NTEN: Nonprofit Technology Network

U.S. Fund for UNICEF

Autism Society Of America

People For The Ethical Treatment of Animals (PETA)

Lights. Camera. Help.

Homes For Our Troops Inc

1736 Family Crisis Center

Total

\begin{tabular}{ccc}
$\begin{array}{c}\text { Total amount } \\
\text { donated }\end{array}$ & $\begin{array}{c}\text { Amount } \\
\text { donated from } \\
\text { Network }\end{array}$ & $\begin{array}{c}\text { Network } \\
\text { Effect }\end{array}$ \\
16,210 & 475 & $3.0 \%$ \\
9,856 & 369 & $3.9 \%$ \\
8,452 & 40 & $0.5 \%$ \\
2,328 & 115 & $5.2 \%$ \\
2,092 & 63 & $3.1 \%$ \\
922 & 48 & $5.4 \%$ \\
1,390 & 48 & $3.6 \%$ \\
2,300 & & $0.0 \%$ \\
557 & 72 & $15.0 \%$ \\
1,181 & 69 & $6.2 \%$ \\
1,857 & 40 & $2.2 \%$ \\
2,939 & 65 & $2.3 \%$ \\
80,913 & 2,956 & $3.8 \%$ \\
\hline
\end{tabular}


Table 7: Broadcasting and Network Pledges: Regression Analysis

The table shows regression estimates where the unit of observation is a pledge $(N=3,160)$. The dependent variable is equal to 1 if a pledge generated a network pledge (i.e., a pledge by one of the original user's Facebook friends or Twitter followers), and 0 otherwise. Linear probability models are employed. Robust standard errors are reported in parentheses.

\begin{tabular}{|c|c|c|c|c|}
\hline & \multicolumn{4}{|c|}{$\begin{array}{c}\text { Outcome variable }=1 \text { if a pledge generated } \\
\text { a network pledge, } 0 \text { otherwise }\end{array}$} \\
\hline & (1) & (2) & (3) & (4) \\
\hline Pledge broadcasted & $\begin{array}{c}0.0648 * * * \\
(0.0069)\end{array}$ & $\begin{array}{c}0.0678 * * * \\
(0.0081)\end{array}$ & $\begin{array}{c}0.0661^{* * *} \\
(0.0086)\end{array}$ & $\begin{array}{c}0.0722^{* * *} \\
(0.0091)\end{array}$ \\
\hline Pledge length (days) & $\begin{array}{c}-0.0001 \\
(0.0001)\end{array}$ & $\begin{array}{c}-0.0001 \\
(0.0001)\end{array}$ & $\begin{array}{l}-0.0001 \\
(0.0001)\end{array}$ & $\begin{array}{l}-0.0000 \\
(0.0001)\end{array}$ \\
\hline Pledge amount (\$) & $\begin{array}{l}-0.0000 \\
(0.0000)\end{array}$ & $\begin{array}{c}0.0000 \\
(0.0000)\end{array}$ & $\begin{array}{l}-0.0000 \\
(0.0001)\end{array}$ & $\begin{array}{l}-0.0000 \\
(0.0002)\end{array}$ \\
\hline N. past pledges & $\begin{array}{c}0.0001 \\
(0.0001)\end{array}$ & $\begin{array}{c}0.0001 \\
(0.0001)\end{array}$ & $\begin{array}{c}0.0002 \\
(0.0001)\end{array}$ & $\begin{array}{c}0.0002 \\
(0.0001)\end{array}$ \\
\hline$\$$ donated in the past & $\begin{array}{l}-0.0000 \\
(0.0000)\end{array}$ & $\begin{array}{r}-0.0000 \\
(0.0000)\end{array}$ & $\begin{array}{l}-0.0000 \\
(0.0000)\end{array}$ & $\begin{array}{r}-0.0000 \\
(0.0000)\end{array}$ \\
\hline Partially fulfilled & $\begin{array}{c}-0.0483^{* * *} \\
(0.0122)\end{array}$ & $\begin{array}{c}-0.0452^{* * *} \\
(0.0135)\end{array}$ & $\begin{array}{l}-0.0400^{*} \\
(0.0239)\end{array}$ & $\begin{array}{l}-0.0364 \\
(0.0249)\end{array}$ \\
\hline Deleted & $\begin{array}{l}-0.0190^{*} \\
(0.0098)\end{array}$ & $\begin{array}{l}-0.0143 \\
(0.0109)\end{array}$ & $\begin{array}{c}-0.0354^{* * *} \\
(0.0125)\end{array}$ & $\begin{array}{c}-0.0272^{* *} \\
(0.0136)\end{array}$ \\
\hline User Fixed Effects & & $x$ & & $x$ \\
\hline Charity Fixed Effects & & & $x$ & $x$ \\
\hline Observations & 3,196 & 3,196 & 3,196 & 3,196 \\
\hline Adjusted R-squared & 0.032 & 0.003 & 0.178 & 0.188 \\
\hline
\end{tabular}




\section{Table 8: Field experiment - Campaign Reach}

This table presents the outcomes of our field-experimental promotional campaigns conducted between June and August, 2012 in collaboration with HelpAttack! and Heifer International. The campaigns consisted of a combination of Facebook ads and sponsored stories, as described in Section 4 in the text. Stage 1 started on June 7 2012, stage 2 on June 22, and Stage 3 on July 27.

\begin{tabular}{lcccc}
\hline & Stage 1 & Stage 2 & Stage 3 & Total \\
\cline { 2 - 5 } Facebook users reached & 484,738 & $3,742,773$ & $2,128,462$ & $6,355,973$ \\
\# of "likes" & 254 & 1,512 & 242 & 2,008 \\
\# of "shares" & 34 & 236 & 33 & 303 \\
\# of comments & 42 & 164 & 7 & 213 \\
\# of "clicks" & 611 & 4,859 & 1,213 & 6,683 \\
(redirected to HA page) & & & & \\
& 3 & 15 & 7 & 25 \\
\# of pledges (Facebook) & 0 & 4 & 1 & 5 \\
\# of pledges (Twitter) & 3 & 19 & 8 & 30 \\
Total \# of pledges & 0 & 1 & 1 & 2 \\
\# deleted or inactive & 3 & 13 & 4 & 20 \\
\# processed & & & &
\end{tabular}


Table 9: Field experiment - Pledges and Network Effects

This table shows the results of the field experiment in terms of initial pledges and network effects, separately for Facebook (8A) and Twitter (8B) users.

\section{A - Facebook}

\begin{tabular}{|c|c|c|c|c|c|c|}
\hline \multirow[b]{4}{*}{ Variable } & \multicolumn{2}{|c|}{ All Subjects } & \multicolumn{2}{|c|}{ Treatment } & \multicolumn{2}{|c|}{ Control } \\
\hline & \multirow{2}{*}{\multicolumn{2}{|c|}{$\begin{array}{l}\text { Intitial pledges }=25 \\
\text { N. of contacts }=4,172\end{array}$}} & \multirow{2}{*}{\multicolumn{2}{|c|}{$\begin{array}{l}\text { Intitial pledges }=13 \\
\text { N. of friends }=2,275\end{array}$}} & \multirow{2}{*}{\multicolumn{2}{|c|}{$\begin{array}{l}\text { Intitial pledges }=12 \\
\text { N. of friends }=1,897\end{array}$}} \\
\hline & & & & & & \\
\hline & Obs & Mean & Obs & Mean & Obs & Mean \\
\hline \multirow[t]{2}{*}{ Female } & 25 & 0.88 & 13 & 0.85 & 12 & 0.92 \\
\hline & & $(0.33)$ & & $(0.38)$ & & $(0.29)$ \\
\hline \multirow[t]{2}{*}{ Facebook Friends } & 25 & 166.88 & 13 & 175.00 & 12 & 158.08 \\
\hline & & (127.14) & & (147.79) & & $(106.20)$ \\
\hline \multirow[t]{2}{*}{ Cents per Update } & 25 & 34.32 & 13 & 32.46 & 12 & 36.33 \\
\hline & & $(36.41)$ & & (39.73) & & (34.09) \\
\hline \multirow[t]{2}{*}{ Amount Donated } & 17 & 14.73 & 8 & 15.27 & 9 & 14.26 \\
\hline & & $(4.26)$ & & $(4.41)$ & & $(4.32)$ \\
\hline \multirow[t]{2}{*}{ Amount Pledged } & 25 & 19.80 & 13 & 18.08 & 12 & 21.67 \\
\hline & & (7.14) & & $(3.84)$ & & $(9.37)$ \\
\hline \multirow[t]{2}{*}{ Length of Pledge } & 25 & 98.40 & 13 & 113.08 & 12 & 82.50 \\
\hline & & (92.27) & & $(104.75)$ & & (77.94) \\
\hline \multirow[t]{2}{*}{ Amount per day } & 17 & 0.41 & 8 & 0.49 & 9 & 0.35 \\
\hline & & $(0.21)$ & & $(0.18)$ & & $(0.21)$ \\
\hline $\begin{array}{l}\text { Additional pledges through } \\
\text { network effect }\end{array}$ & & 0 & & 0 & & 0 \\
\hline $\begin{array}{l}\text { Additional amount donated } \\
\text { through network effect }\end{array}$ & & 0 & & 0 & & 0 \\
\hline
\end{tabular}

\section{B - Twitter}

\begin{tabular}{|c|c|c|c|c|c|c|}
\hline \multirow[b]{3}{*}{ Variable } & \multicolumn{2}{|c|}{ All Subjects } & \multicolumn{2}{|c|}{ Treatment } & \multicolumn{2}{|c|}{ Control } \\
\hline & \multicolumn{2}{|c|}{$\begin{array}{c}\text { Intitial pledges }=5 \\
\text { N. of followers }=2,844\end{array}$} & \multicolumn{2}{|c|}{$\begin{array}{c}\text { Intitial pledges }=3 \\
\text { N. of followers }=2,409\end{array}$} & \multicolumn{2}{|c|}{$\begin{array}{l}\text { Intitial pledges }=2 \\
\text { N. of followers }=435\end{array}$} \\
\hline & Obs & Mean & Obs & Mean & Obs & Mean \\
\hline \multirow[t]{2}{*}{ Friends } & 5 & 444.60 & 3 & 703.67 & 2 & 56.00 \\
\hline & & (499.57) & & (497.43) & & $(5.66)$ \\
\hline \multirow[t]{2}{*}{ Followers } & 5 & 568.80 & 3 & 803.00 & 2 & 217.50 \\
\hline & & (823.67) & & $(1066.26)$ & & $(169.00)$ \\
\hline \multirow[t]{2}{*}{ Cents Per Update } & 5 & 178.40 & 3 & 247.33 & 2 & 75.00 \\
\hline & & $(274.36)$ & & $(363.46)$ & & (35.36) \\
\hline \multirow[t]{2}{*}{ Amount Donated } & 3 & 18.21 & 2 & 17.31 & 1 & 20.00 \\
\hline & & (3.11) & & $(3.80)$ & & \\
\hline \multirow[t]{2}{*}{ Amount Pledged } & 5 & 36.00 & 3 & 20.00 & 2 & 60.00 \\
\hline & & (35.78) & & 0.00 & & $(56.57)$ \\
\hline \multirow[t]{2}{*}{ Length of Pledge } & 5 & 72.00 & 3 & 30.00 & 2 & 135.00 \\
\hline & & (93.91) & & 0.00 & & (148.49) \\
\hline \multirow[t]{2}{*}{ Amount per day } & 3 & 0.61 & 2 & 0.58 & 1 & 0.67 \\
\hline & & $(0.10)$ & & $(0.13)$ & & \\
\hline $\begin{array}{l}\text { Additional pledges through } \\
\text { network effect }\end{array}$ & & 1 & & 0 & & 1 \\
\hline $\begin{array}{l}\text { Additional amount donated } \\
\text { through network effect }\end{array}$ & & 20 & & 0 & & 20 \\
\hline
\end{tabular}


Table 10: Survey experiment - wording of the key question in the control condition and in each of the treatment

The order of the statements was randomized in two different versions. In particular, the treatment statements appeared in either the 2nd or 4th position.

\section{Question: Please read the statements below and indicate how many apply to you.}

Statements common to control and treatment conditions

There are several operating systems for smartphones. I am familiar with the Google Android operating system.

Suppose the Government increases income taxes by $0.5 \%$. I would support using the proceedings to improve the public school system.

If I had to replace my phone today, I would buy an iPhone.

I am in favor of expanding offshore drilling to reach energy independence.

\section{Additional statements added in each treatment condition}

$A R C$, No fee

ARC, With fee

$A R C$, With fee and intermediary

Heifer, No fee

Heifer, With fee

Heifer, With fee and intermediary

Charity of choice, No fee

Charity of choice, With fee

Charity of choice, With fee and

intermediary
If I was given $\$ 10$ and could either keep the full amount or donate $\$ 5$ to the American Red Cross, I would choose to donate $\$ 5$ to the American Red Cross.

If I was given $\$ 10$ and could either keep the full amount or donate $\$ 5$ to the American Red Cross, I would choose to donate $\$ 5$ to the American Red Cross ( $8.25 \%$ of your donation will be used to cover processing fees)

If I was given $\$ 10$ and could either keep the full amount or donate $\$ 5$ to the American Red Cross, I would choose to donate $\$ 5$ to the American Red Cross ( $8.25 \%$ of your donation will be used to cover processing fees by an intermediary agent organization)

If I was given $\$ 10$ and could either keep the full amount or donate $\$ 5$ to Heifer International, I would choose to donate $\$ 5$ to Heifer International.

If I was given $\$ 10$ and could either keep the full amount or donate $\$ 5$ to Heifer International, I would choose to donate $\$ 5$ to Heifer International ( $8.25 \%$ of your donation will be used to cover processing fees)

If I was given $\$ 10$ and could either keep the full amount or donate $\$ 5$ to Heifer International, I would choose to donate $\$ 5$ to the Heifer International ( $8.25 \%$ of your donation will be used to cover processing fees by an intermediary agent organization)

If I was given $\$ 10$ and could either keep the full amount or donate $\$ 5$ to a charity of my choice, I would choose to donate $\$ 5$ to a charity of my choice.

If I was given $\$ 10$ and could either keep the full amount or donate $\$ 5$ to a charity of my choice, I would choose to donate $\$ 5$ to a charity of my choice $(8.25 \%$ of your donation will be used to cover processing fees)

If I was given $\$ 10$ and could either keep the full amount or donate $\$ 5$ to a charity of my choice, I would choose to donate $\$ 5$ to a charity of my choice $(8.25 \%$ of your donation will be used to cover processing fees by an intermediary agent organization) 
Table 11: Survey experiment - sample distribution across treatments and randomization check

The table reports the number of subjects per conditions as well as the average values of the responses to the various questions in the survey, by treatment condition. Note that in some case these means are meaningful (e.g. for age or for binary responses such as gender and whether the subject has children or has volunteered in the past). In other cases, averages are taken over categorical variables. Within the categorical variables we report the value ranges for the cases where the options were following some plausible order (educational attainment and income) but not for those where there is no ranking (employment status, religion, and political views).

\begin{tabular}{|c|c|c|c|c|c|c|c|c|c|c|}
\hline Condition & $\mathbf{N}$ & Age & Female & No children & $\begin{array}{c}\text { Highest } \\
\text { education (1-6) }\end{array}$ & $\begin{array}{l}\text { Employment } \\
\text { status }\end{array}$ & Income (1-5) & $\begin{array}{c}\text { Has } \\
\text { voluntered }\end{array}$ & Religion & $\begin{array}{l}\text { Political } \\
\text { views }\end{array}$ \\
\hline Control & 158 & 33.0 & 0.4 & 0.7 & 4.5 & 2.7 & 2.7 & 0.7 & 1.7 & 2.1 \\
\hline ARC, No fee & 152 & 32.1 & 0.4 & 0.6 & 4.4 & 2.7 & 2.7 & 0.6 & 1.5 & 2.2 \\
\hline ARC, With fee & 166 & 31.7 & 0.4 & 0.7 & 4.5 & 2.9 & 2.7 & 0.7 & 1.6 & 2.1 \\
\hline $\begin{array}{l}\text { ARC, With fee and } \\
\text { intermediary }\end{array}$ & 154 & 33.1 & 0.4 & 0.7 & 4.3 & 2.7 & 2.7 & 0.8 & 1.7 & 2.1 \\
\hline Heifer, No fee & 161 & 32.2 & 0.4 & 0.6 & 4.3 & 2.7 & 2.8 & 0.7 & 1.7 & 2.2 \\
\hline Heifer, With fee & 172 & 30.3 & 0.4 & 0.7 & 4.5 & 2.7 & 2.8 & 0.7 & 1.7 & 2.2 \\
\hline $\begin{array}{l}\text { Heifer, With fee and } \\
\text { intermediary }\end{array}$ & 161 & 30.8 & 0.5 & 0.8 & 4.2 & 3.2 & 2.4 & 0.6 & 1.6 & 2.2 \\
\hline Charity of choice, No fee & 162 & 30.6 & 0.4 & 0.7 & 4.5 & 3.0 & 2.5 & 0.7 & 1.6 & 2.2 \\
\hline Charity of choice, With fee & 158 & 30.2 & 0.4 & 0.7 & 4.4 & 3.1 & 2.6 & 0.7 & 1.6 & 2.2 \\
\hline $\begin{array}{l}\text { Charity of choice, With fee } \\
\text { and intermediary }\end{array}$ & 161 & 32.3 & 0.4 & 0.7 & 4.3 & 3.0 & 2.5 & 0.6 & 1.8 & 2.2 \\
\hline
\end{tabular}


Table 12: Survey experiment - descriptive statistics on additional questions (control variables) $\mathrm{N}=1,605$ subjects.

\begin{tabular}{|c|c|c|c|}
\hline \multicolumn{2}{|c|}{ Age } & \multicolumn{2}{|c|}{ Employment status } \\
\hline 30 and below & $59.8 \%$ & Private Employee & $36.0 \%$ \\
\hline $31-50$ & $32.7 \%$ & Public Employee & $13.9 \%$ \\
\hline Above 50 & $7.5 \%$ & Self-employed/Entrepreneur & $15.7 \%$ \\
\hline & 31.2 & Unemployed & $13.3 \%$ \\
\hline & & Housekeeper & $4.4 \%$ \\
\hline \multicolumn{2}{|c|}{ Gender } & Student & $15.0 \%$ \\
\hline Male & $59.6 \%$ & Retired & $1.8 \%$ \\
\hline Female & $40.4 \%$ & & \\
\hline
\end{tabular}

\begin{tabular}{lr}
\multicolumn{2}{c}{ Race/ethnicity } \\
\hline White/caucasian & $77.3 \%$ \\
African American & $6.5 \%$ \\
Hispanic & $6.0 \%$ \\
Asian & $8.6 \%$ \\
Other & $1.6 \%$
\end{tabular}

\begin{tabular}{lr}
\multicolumn{2}{c}{ Relationship status } \\
\hline Single & $41.4 \%$ \\
Unmarried in a relationship & $24.0 \%$ \\
Married & $29.2 \%$ \\
Separated/divorces & $4.8 \%$ \\
Other & $0.6 \%$
\end{tabular}

Highest educational level attained

Completed primary school $\quad 0.0 \%$

Some high school $\quad 0.9 \%$

Completed high school $\quad 13.3 \%$

Some college $\quad 39.1 \%$

Completed college $\quad 37.9 \%$

Postgraduate $\quad 8.7 \%$

\begin{tabular}{|c|c|c|c|}
\hline \multicolumn{2}{|c|}{ Has children } & \multicolumn{2}{|c|}{ Donated or volunteered in the past 2 years } \\
\hline Yes & $31.7 \%$ & Yes & $68.9 \%$ \\
\hline No & $68.3 \%$ & No & $31.1 \%$ \\
\hline
\end{tabular}


Table 13: Survey experiment - regression analyses

The table reports the parameter estimates from Equation (1), limited to the main parameters of interest. The bottom section of the table displays the estimated differences of the effects between some conditions of interest. Standard errors are in parentheses. ${ }^{*} \mathrm{p}<0.1$; ${ }^{* *} \mathrm{p}<0.05$; ${ }^{* * *} \mathrm{p}<0.01$

\begin{tabular}{|c|c|c|c|c|c|c|c|c|}
\hline & (1) & (2) & (3) & (4) & (5) & (6) & (7) & (8) \\
\hline ARC combined & $\begin{array}{c}0.40 * * * \\
(0.09)\end{array}$ & $\begin{array}{c}0.40 * * * \\
(0.09)\end{array}$ & & & & & & \\
\hline Heifer combined & $\begin{array}{l}0.23^{* *} \\
(0.09)\end{array}$ & $\begin{array}{c}0.23^{* * *} \\
(0.09)\end{array}$ & & & & & & \\
\hline $\begin{array}{l}\text { Charity of choice } \\
\text { combined }\end{array}$ & $\begin{array}{c}0.38^{* * *} \\
(0.09)\end{array}$ & $\begin{array}{c}0.39 * * * \\
(0.09)\end{array}$ & & & & & & \\
\hline With fee combined & & & $\begin{array}{l}0.29 * * * \\
(0.09)\end{array}$ & $\begin{array}{c}0.29 * * * \\
(0.08)\end{array}$ & & & & \\
\hline No fee Combined & & & $\begin{array}{c}0.43^{* * *} \\
(0.09)\end{array}$ & $\begin{array}{c}0.44 * * * \\
(0.09)\end{array}$ & & & & \\
\hline $\begin{array}{l}\text { With fee and } \\
\text { intermediaty }\end{array}$ & & & & & $\begin{array}{l}0.23 * * \\
(0.09)\end{array}$ & $\begin{array}{c}0.24 * * * \\
(0.09)\end{array}$ & & \\
\hline $\begin{array}{l}\text { With fee and no } \\
\text { intermediary }\end{array}$ & & & & & $\begin{array}{c}0.34 * * * \\
(0.09)\end{array}$ & $\begin{array}{c}0.33^{* * *} \\
(0.09)\end{array}$ & & \\
\hline ARC, No fee & & & & & & & $\begin{array}{l}0.52 * * * \\
(0.11)\end{array}$ & $\begin{array}{c}0.54 * * * \\
(0.11)\end{array}$ \\
\hline ARC, With fee & & & & & & & $\begin{array}{c}0.37^{* * *} \\
(0.11)\end{array}$ & $\begin{array}{c}0.36 * * * \\
(0.11)\end{array}$ \\
\hline $\begin{array}{l}\text { ARC, With fee and } \\
\text { intermediary }\end{array}$ & & & & & & & $\begin{array}{c}0.30^{* * *} \\
(0.11)\end{array}$ & $\begin{array}{c}0.29 * * * \\
(0.11)\end{array}$ \\
\hline Heifer, No fee & & & & & & & $\begin{array}{c}0.34^{* * *} \\
(0.11)\end{array}$ & $\begin{array}{c}0.34 * * * \\
(0.11)\end{array}$ \\
\hline Heifer, With fee & & & & & & & $\begin{array}{c}0.16 \\
(0.11)\end{array}$ & $\begin{array}{c}0.15 \\
(0.11)\end{array}$ \\
\hline $\begin{array}{l}\text { Heifer, With fee and } \\
\text { intermediary }\end{array}$ & & & & & & & $\begin{array}{l}0.18^{*} \\
(0.11)\end{array}$ & $\begin{array}{l}0.22 * * \\
(0.11)\end{array}$ \\
\hline $\begin{array}{l}\text { Charity of choice, No } \\
\text { fee }\end{array}$ & & & & & & & $\begin{array}{c}0.43^{* * *} \\
(0.11)\end{array}$ & $\begin{array}{c}0.44^{* * *} \\
(0.11)\end{array}$ \\
\hline $\begin{array}{l}\text { Charity of choice, } \\
\text { With fee }\end{array}$ & & & & & & & $\begin{array}{c}0.51^{* * *} \\
(0.11)\end{array}$ & $\begin{array}{c}0.50 * * * \\
(0.11)\end{array}$ \\
\hline $\begin{array}{l}\text { Charity of choice, } \\
\text { With fee and } \\
\text { intermediary }\end{array}$ & & & & & & & $\begin{array}{l}0.21^{*} \\
(0.11)\end{array}$ & $\begin{array}{l}0.23^{* *} \\
(0.11)\end{array}$ \\
\hline Controls & & $x$ & & $x$ & & $x$ & & $x$ \\
\hline Observations & 1,605 & 1,604 & 1,605 & 1,604 & 1,130 & 1,130 & 1,605 & 1,604 \\
\hline \multirow[t]{2}{*}{ Adjusted R-squared } & 0.013 & 0.052 & 0.013 & 0.051 & 0.011 & 0.042 & 0.019 & 0.057 \\
\hline & $\begin{array}{l}\text { ARC - Heifer } \\
\text { Char. of choi } \\
\text { Char. of choi }\end{array}$ & $\begin{array}{l}* * \\
\text { CC: }-0.02 \\
\text { ifer: } 0.15^{* *}\end{array}$ & No fee - Wit & $0.14^{* * *}$ & $\begin{array}{l}\text { With fee, no } \\
\text { With fee anc } \\
0.11^{* *}\end{array}$ & $\begin{array}{l}\text { nediary - } \\
\text { mediary: }\end{array}$ & & \\
\hline
\end{tabular}

